\title{
Protection of organs other than the heart by remote ischemic conditioning
}

\author{
Candilio L*, Malik A*, Hausenloy DJ
}

*Dr Candilio and Dr Malik contributed equally and are joint first authors

Corresponding author:

Dr Derek J Hausenloy,

The Hatter Cardiovascular Institute,

University College London,

67 Chenies Mews,

London, WC1E 6HX, United Kingdom.

Tel: $\quad+442034479888$

Fax: +442034475095

Email: d.hausenloy@ucl.ac.uk 


\section{Abstract}

Organ or tissue dysfunction due to acute ischemia-reperfusion injury (IRI) is the leading cause of death and disability worldwide. Acute IRI induces cell injury and death in a wide variety of organs and tissues in a large number of different clinical settings. One novel therapeutic non-invasive intervention, capable of conferring multi-organ protection against acute IRI, is 'remote ischemic conditioning' (RIC). This describes an endogenous protective response to acute IRI, which is triggered by the application of one or more brief cycles of non-lethal ischemia and reperfusion to one particular organ or tissue. Originally discovered as a therapeutic strategy for protecting the myocardium against acute IRI, it has been subsequently demonstrated that RIC may confer protection against acute IRI in a number of different non-cardiac organs and tissues including the kidneys, lungs, liver, skin flaps, ovaries, intestine, stomach and pancreas. The discovery that RIC can be induced non-invasively by applying the RIC stimulus to the skeletal tissue of the upper or lower limb, has facilitated its application to a number of clinical settings in which organs and tissues are at high-risk of acute IRI. In this article, we review the experimental studies which have investigated RIC in organs and tissues other than the heart, and we explore the therapeutic potential of RIC in preventing organ and tissue dysfunction induced by acute IRI.

\section{Keywords:}

Ischemia, reperfusion, remote ischemic preconditioning, remote ischemic perconditioning, remote ischemic postconditioning. 


\section{Introduction}

Organ or tissue dysfunction arising from acute $\mid \mathrm{RI}$ is the leading cause of death and disability worldwide. Acute IRI induces cell injury and death in a large number of different clinical settings and in a wide variety of organs and tissues including the heart, kidneys, liver, intestine, lungs, brain, skeletal muscle, pancreas, skin, and ovaries. The pathophysiology of IRI and its effects on cellular function and viability are largely similar in these different organs and tissues. It follows then that novel therapeutic strategies for protecting against acute IRI appear to be similarly efficacious in these different organs and tissue. This appears to be the case with the endogenous protective response of remote ischemic conditioning (RIC), in which the application of one or more brief cycles of non-lethal ischemia and reperfusion in one organ or tissue confers protection in remote organs or tissues from a sustained lethal acute episode of $|R|^{1,2}$. The majority of the experimental studies investigating $R I C$ as a protective therapeutic strategy against acute $I R I$ have revolved around the heart, and this topic is reviewed elsewhere in this special issue. In this article, we focus on the experimental studies which have investigated RIC in organs and tissues other than the heart, and we discuss the therapeutic potential application of RIC for preventing organ and tissue dysfunction in the clinical setting.

\section{Remote ischemic conditioning as an evolving protective strategy}

The discovery that the myocardium could be protected against a sustained lethal episode of acute IRI, by subjecting it to one or more brief cycles of non-lethal ischemia and reperfusion, was originally made in 1986 by Murry et al ${ }^{3}$. This endogenous protective response against acute IRI, which was termed ischemic preconditioning' (IPC), has been reported to confer cross-species protection in all 
organs and tissue it has been investigated in ${ }^{4}$. However, the major disadvantage of IPC is the need to intervene before the index ischemic event, thereby limiting its clinical application ${ }^{5}$. This was overcome by the introduction of the concept of ischemic postconditioning in 2003 by Zhao et al. ${ }^{6}$ who demonstrated that interrupting myocardial reperfusion with several short-lived episodes of intermittent myocardial ischemia, so as to 'stutter' the reperfusion phase, could reduce myocardial infarct size in the canine heart, providing a therapeutic cardioprotective strategy which could be applied at reperfusion. However, the disadvantage of both IPC and IPost as treatment strategies is that both approaches require the intervention to be applied to the organ or tissue directly, which in some cases may not be feasible or practical ${ }^{7}$. This obstacle was overcome by the discovery of 'remote ischemic preconditioning' (RIPC) in $1993^{1}$, a therapeutic strategy for protecting organs and tissues against acute IRI by applying the protective stimulus away from the target organ or tissue.

The concept of protecting an organ or tissue against acute $|\mathrm{R}|$ at a distance was first conceived in a seminal experimental study in 1993 by Przyklenk et al ${ }^{1}$. These authors demonstrated in the canine heart, that applying four 5-minute episodes of left circumflex branch occlusion and 5-minute reflow, reduced myocardial infarct (MI) size induced by 1 hour of sustained left anterior descending (LAD) coronary artery occlusion and 4.5 hours of reflow ${ }^{1}$. The concept that protection against acute $\mathrm{IRI}$ could be transferred from one coronary artery territory to another was then extended to protecting the heart at a distance by applying the preconditioning stimulus to an organ 'remote' from the heart by McClanahan et al in $1993^{8}$. These authors demonstrated that subjecting the kidney to brief cycles of nonlethal ischemia and reperfusion (IR) could limit subsequent MI size in the rat heart ${ }^{8}$. 
Later in 1997, Birnbaum et al ${ }^{9}$ made the important discovery that RIPC could be induced by subjecting the skeletal muscle of the hind-limb to brief cycles of nonlethal ischemia and reperfusion. These authors observed, that briefly restricting blood flow to the skeletal muscle of the lower limb and pacing the gastrocnemius leg muscle prior to an acute coronary artery occlusion, reduced $\mathrm{Ml}$ size in the rabbit heart ${ }^{9}$. A non-invasive method for applying the RIPC stimulus to the hind-limb using external compression with a tourniquet was then introduced by Oxman et al ${ }^{10}$, a finding which has greatly facilitated the translation of RIPC as an experimental phenomenon into a potential non-invasive therapeutic strategy in the clinical setting.

In this regard, the first clinical study to investigate RIPC in patients was by Gunaydin et al in $2000{ }^{11}$, who inflated and deflated a standard blood pressure cuff placed on the upper arm to non-invasively induce the RIC stimulus in patients prior to coronary artery bypass graft (CABG) surgery. However, the study was underpowered to detect any meaningful differences in the effect of RIC on perioperative myocardial injury. Later in 2002, Kharbanda et al ${ }^{12}$ characterized in human volunteers a simple non-invasive RIPC protocol (three-5 min inflations/deflations of an upper arm blood pressure cuff) using flow-mediated dilatation as the measured endpoint of endothelial function.

Crucially, experimental studies have demonstrated that the RIC stimulus does not have to be applied prior to the index ischemic event to be effective (as in 'remote ischemic preconditioning' or RIPC), but can be applied after the onset of index ischemia (termed 'remote ischemic perconditioning' or RIPerC) ${ }^{13}$, and even at the time of reperfusion (termed 'remote ischemic postconditioning' or RIPost) ${ }^{14,15}$. The finding that the RIC stimulus can be effective when delivered at different time-points during the index episode of acute IRI has also increased it applicability to a number 
of different clinical settings. The term, remote ischemic conditioning (RIC), has been introduced to refer to these different protective phenomena and will be used from this point forward.

The recognition that a single RIC stimulus could confer multi-organ and tissue protection against acute IRI has led to it being extensively investigated not only in the field of myocardial protection but also in a wide variety of other non-cardiac organs or tissues such as the kidneys, lungs, liver, brain, stomach, intestine, pancreas and ovaries, in which acute $I R I$ also causes significant morbidity and mortality. The mechanisms underlying $\mathrm{RIC}$ protection against acute $I R I$ remain uncertain and are discussed elsewhere in this special issue. Throughout this review article, the reader will note the widely varying RIC protocols that have been used in the experimental studies. Unfortunately, insufficient work has been undertaken to ascertain the optimal RIC protocol in terms of its efficacy. If RIC is to succeed as a clinical applicable intervention both these issues will need to be addressed by further experimental study.

\section{Remote ischemic conditioning and the kidney}

Acute kidney injury $(\mathrm{AKI})$ due to acute $\mathrm{IRI}$ is a frequent cause of morbidity and mortality following a number of medical conditions and operative procedures. $\mathrm{AKI}$ is a condition frequently encountered in the period that follows major surgery and which is associated with significant morbidity and mortality. In the setting of cardiac surgery it can affect up to $30 \%$ of patients resulting in renal dialysis, in $1-2 \%$ of cases $^{16}$, the

repercussions of which include an eight-fold increase in death rate ${ }^{17}$. AKI is also a common complication of major vascular surgery involving the abdominal aorta, and can occur in up to $10 \%$ of these patients ${ }^{18}$, where it is an independent predictor of 
death ${ }^{19}$. Aortic cross-clamping and de-clamping during the surgical procedure subjects the kidneys to acute $\mid \mathrm{RI}{ }^{20}$.

Different mechanisms have been hypothesized to explain the etiology underlying renal injury following cardiac surgery and these include hemodynamic effects related to cardiopulmonary bypass (CBP), metabolic factors, neuro-hormonal stimulation, the systemic inflammatory response to CBP, exogenous and endogenous toxins, and the production of micro-emboli and oxidative stress ${ }^{16}$. Importantly, despite a number of different preventative strategies being investigated to preserve renal function following cardiac surgery, the results have been disappointing ${ }^{16}$. Therefore, novel renoprotective strategies are required to protect the kidneys against acute IRI in order to reduce the incidence of AKI and improve clinical outcomes in these patients.

\subsection{The experimental data for RIC as a renoprotective strategy}

A number of experimental studies have investigated the effect of IPC as a therapeutic strategy for limiting acute renal IRI (reviewed in ${ }^{21}$ ). However, only a few experimental studies have explored the effect of RIC in preventing acute IRI in the kidney (see Table 1a). Beneficial effects have been reported using a diverse variety of RIC protocols applied to different organs or tissues including the liver, small intestine, subphrenic aorta and the hindlimb. The study by Wever et al ${ }^{22}$, which used limb RIC, attempted to characterize the RIC stimulus, and as expected they were able to show that the protective effect was augmented when the RIC stimulus was applied to both hindlimbs instead of one. Importantly, Kadkhodaee et al ${ }^{23}$ demonstrated that the RIC limb stimulus was effective even when applied after the onset of index renal ischemia (RIPerC) and even at the onset of renal reperfusion 
(RIPost), thereby broadening the clinical application of RIC as a therapeutic renoprotective strategy. Finally, the concept of combining renoprotective stimuli has been recently investigated by Wever et al ${ }^{24}$, who demonstrated the synergistic effects on preserving renal function using RIPost and a local IPost protocol in combination.

\subsection{The clinical data for RIC as a renoprotective strategy}

Several clinical studies have investigated the effect of RIC using repeated cycles of upper arm or leg ischemia and reperfusion on preventing renal dysfunction and the development of acute kidney injury (AKI) following a number of medical and surgical procedures including percutaneous coronary intervention (PCI), CABG surgery, renal transplantation, abdominal aortic aneurysm surgery, and other major vascular

surgery (see Table 1b). However, not all the clinical studies have reported a beneficial effect of RIC as a renoprotective strategy with some studies being neutral. The reasons for the mixed results are multi-factorial and have been discussed in relation to myocardial protection in several recently published articles ${ }^{25-28}$. The majority of the clinical studies have investigated the protective effect of RIC against acute renal $\mid R I$, although a recently published trial reported beneficial effects against contrast-induced $\mathrm{AKI}$ during elective $\mathrm{PCl}^{29}$, a condition which affects up to $12 \%$ of patients with coronary heart disease (CHD) undergoing elective PCI.

Whether RIC can actually improve clinical outcomes following acute renal IRI is currently being investigated in two large multi-centre randomized controlled clinical trials. The ERICCA trial (ClinicalTrials.gov Identifier: NCT01247545), is currently investigating the effect of RIC (four-5 min upper arm cuff inflations/deflations) on post-operative renal function, renal biomarkers, the development of $\mathrm{AKI}$, and major 
adverse cardiovascular events in adult patients undergoing CABG plus or minus valve surgery ${ }^{30}$. The REPAIR trial (ISRCTN30083294) is currently investigating the effect of RIC (three-5 min upper arm cuff inflations/deflations) applied to both the donor and recipient on post-operative renal function and renal biomarkers in patients undergoing live donor-related renal transplantation.

\section{Remote ischemic conditioning and the lungs}

Acute lung injury is a major cause of morbidity and mortality in a number of clinical settings including cardiac surgery, orthopedic surgery, lung resection surgery and lung transplantation. In the setting of CABG surgery, the main contributory mechanisms underlying pulmonary dysfunction include cardiopulmonary bypass (CBP)-induced systemic cytokine-mediated inflammatory response and acute lung IRI ${ }^{31}$, resulting in poor alveolar oxygenation and increased pulmonary vascular resistance leading to prolonged requirement for artificial ventilation ${ }^{32,33}$.

\subsection{The experimental data for RIC as a lung protective strategy}

One of the first experimental studies to investigate the effect of RIC on acute lung injury was by Peralta et al in $2002{ }^{34}$ who demonstrated in the rat that applying a RIC stimulus to the liver reduced systemic inflammation and attenuated neutrophil accumulation in the lung and other organs following a sustained liver IRI. Since this study a number of studies have examined the effect of RIC in preventing acute lung IRI in a wide variety of experimental models (see Table 2a). 


\subsection{The clinical data for RIC as a lung protective strategy}

A number of clinical studies have investigated the effect of RIC on pulmonary function following mainly cardiac surgery, although there has been one study in orthopaedic surgery (see Table 2b). The first clinical study to demonstrate a beneficial effect of RIC on pulmonary function was by $\mathrm{Li}$ et al in $200{ }^{35}$ who demonstrated that RIC of the heart could preserve pulmonary function following adult cardiac valve surgery. However, in the majority of the clinical studies, the main objective has been to evaluate the effect of RIC on cardioprotection, and the endpoints of pulmonary function, were usually secondary objectives of the study. In this regard, RIC appears to have some beneficial effects on preserving pulmonary function in pediatric cardiac surgery and following orthopedic surgery. However, it appears that RIC has little effect on ventilation times following adult cardiac surgery, which may be expected given that there are a large number of factors other than acute IRI which contribute to the length of ventilation post-cardiac surgery. It will be interesting to examine the effect of RIC in clinical settings in which acute lung IRI is the predominant insult such as in cases of lung resection surgery and lung transplantation. In this regard, on-going clinical studies are currently evaluating the effects of RIC on pulmonary function in the setting of pulmonary lobectomy (ClinicalTrials.gov identifier: NCT01307085) and elective abdominal aortic aneurysm repair (ClinicalTrials.gov NCT01344239).

\section{Remote ischemic conditioning and the liver}

During major liver surgery, intra- or post-operative blood loss with subsequent requirement of blood transfusion is associated with worse clinical outcomes ${ }^{36,37}$. Vascular clamping of the hepatic territory can prevent or minimise this risk although it 
is itself associated with acute liver IRI due to clamping and subsequent unclamping of the portal triad ${ }^{38,39}$. The mechanism underlying acute hepatic IRI is likely to be related to the significant amount of oxygen-derived free radicals accumulating in the liver during reperfusion, particularly in those cases of resected or cirrhotic liver when acute IRI is poorly tolerated due to impaired compensatory mechanisms, leading to post-operative hepatic and multi-organ failure ${ }^{38}$.

\subsection{The experimental data for RIC as a liver protective strategy}

The first experimental study to demonstrate benefit with limb RIC was by Lai et al ${ }^{40}$ who found that four-10 min cycles of hind-limb ischemia and reperfusion reduced acute liver IRI as evidenced by an attenuated increase in the serum liver enzyme ALT (alanine aminotransferase). In this initial study, RIC protection was associated with the activation of hemoxygenase-1 (HO-1), a known mediator of direct IPC ${ }^{40}$. Since this publication, a number of experimental studies, using a wide variety of different RIC protocols, have confirmed the protective effects of limb RIC against acute liver $\mid \mathrm{RI}$ in the rat, rabbit and mouse (see Table 3 for summary). The mechanism underlying the protective effect is unclear, although potential mediators include components of the nitric oxide pathway (sGC, cGMP, eNOS) ${ }^{41-43}$ and the Toll-4 receptor signalling pathway. An exciting recent study has suggested that limb RIC may not only be able to protect against acute liver IRI, but it may actually promote liver regeneration in small liver grafts following liver transplantation ${ }^{44}$. Wang et al ${ }^{44}$ demonstrated that a standard limb RIC protocol increased the proliferation index in the liver graft, findings which were associated with enhanced expression of interleukin-6 mRNA and suppressed expression of TNF- $\alpha$. 


\subsection{The clinical data for RIC as a liver protective strategy}

Two randomised controlled clinical trials are currently investigating the therapeutic potential of RIC in the clinical setting of acute hepatic IRI. In the first study, based in the UK, Davidson and colleagues are exploring whether RIC (three-10 min cycles thigh cuff inflation/deflation) can reduce acute liver IRI (serum hepatic and tissue biomarkers) in patients undergoing liver surgery and orthotopic liver transplantation (ClinicalTrials.gov identifier: NCT00796588). In the second study, based in the USA, Koneru and colleagues will evaluate short and long-term clinical outcomes in patients receiving liver, kidney or pancreas transplantation from deceased organ donors previously randomised to either RIC (two-10 min cycles of inflation/deflation of a blood pressure cuff applied sequentially on each leg) (Remote Ischemic Preconditioning In Abdominal Organ Transplantation [RIPCOT]; ClinicalTrials.gov identifier: NCT00975702). The results from these two studies should inform us of the therapeutic potential of RIC in preventing acute liver IRI in patients undergoing major abdominal surgery or organ transplantation.

\section{Remote ischemic conditioning and the brain}

There are a number of clinical settings in which the brain is subjected to acute IRI including the setting of stroke and during carotid endarterectomy (CEA). Stroke is currently the second most common cause of death worldwide, after coronary artery disease ${ }^{45}$, and is responsible for nearly $10 \%$ of all deaths around the world ${ }^{46}$. In 2002, stroke-related disability was estimated as the fifth most common cause of reduced disability-adjusted life-years (DALYs-the sum of life-years lost as a result of premature death and years lived with disability adjusted for severity) in low-income and middle-income countries ${ }^{46}$. CEA has been recognised as an effective strategy 
for stroke prevention in both symptomatic and asymptomatic patients ${ }^{47-50}$. However CEA itself carries important peri-operative risks, with an estimated mortality rate of $1 \%$, perioperative stroke rate of $3-5 \%$, and a major cardiac complication rate (myocardial infarction, unstable angina, pulmonary edema, or ventricular tachycardia) of $4 \%{ }^{51,52}$.

\subsection{The experimental data for RIC as a neuroprotective strategy}

As a potentially novel neuroprotective intervention, RIC has been extensively studied in the pre-clinical literature. Experimental studies have evaluated RIC from a number of different perspectives: (1) a number of different species have been investigated including mouse, rat, rabbit and pig; (2) the timing of the RIC stimulus in relation to the acute IRI; (3) site of the RIC stimulus (mainly the limb but also other organs); (4) A variety of conditions including acute brain IRI (cerebral infarction, cerebral asphyxia, hypothermic circulatory arrest, and neonatal cerebral hypoxia) and spinal injury (Table 4). The first experimental study to evaluate RIC as a neuroprotective strategy was by Dave et al ${ }^{53}$ who found that RIC (either a single episode of 15 or 30 minutes of hindlimb ischemia and reperfusion) could protect the rat brain against acute IRI induced by asphyxial cardiac arrest. Crucially, the RIC stimulus has been shown to be effective at a number of different time-points in relation to the cerebral IRI broadening its scope for application in the clinical setting. The RIC stimulus can be applied one or two days prior to the index cerebral ischemia (delayed RIPC), immediately prior to the index cerebral ischemia (classical RIPC), after the onset of the index cerebral ischemia (RIPerC), at the onset of cerebral reperfusion (RIPost) ${ }^{54}$ and even when delayed up to 3 hours into the reperfusion phase (delayed RIPost) ${ }^{54}$ (Table 4). The ability to protect the brain against acute IRI with the RIC delivered 3 
hours into reperfusion would have important clinical implications. Whether delaying the RIC stimulus into reperfusion is effective in protecting other organs or tissue against acute IRI is unknown, although this approach does appear to contradict the current paradigm that, for a protective intervention to be effective it needs to be applied at the onset of reperfusion. Interestingly, a recent experimental study has demonstrated that local IPost applied direct to the heart could limit myocardial infarct size in a murine model of acute IRI, even when delivered up to $30 \mathrm{~min}$ into reperfusion ${ }^{55}$.

\subsection{The clinical data for RIC as a neuroprotective strategy}

Several small proof-of-concept randomised controlled clinical trials have been published investigating the neuroprotective effect of limb RIC. In a phase 1b study, Koch et al ${ }^{56}$ demonstrated that RIC could be safely applied to 33 critically ill subjects presenting with aneurysmal subarachnoid haemorrhage (SAH). Hu et al ${ }^{57}$ demonstrated significant reductions of post-operative serum markers of cerebral ischemic injury (S-100B and neurone-specific elonase) and improvements in neurological recovery in 20 patients with cervical spondylotic myelopathy undergoing elective cervical decompression, when compared to similar control subjects. Walsh et al ${ }^{58}$ evaluated the effects of RIC (10 minutes of ischemia-reperfusion applied with a blood pressure cuff sequentially to each leg) prior to clamping of the carotid artery in 70 patients undergoing elective CEA. This study failed to demonstrate any significant effect on saccadic latency deteriorations (a marker of cerebral injury following CEA). A recent clinical trial has evaluated the effect of RIC (four -5 min arm cuff inflations/deflations) on cerebral infarct size in 151 acute ischemic stroke patients undergoing thrombolysis, but this ground-breaking clinical trial failed to find 
any significant effect on cerebral infarct size or neurological recovery ${ }^{59}$. There are currently a number of on-going clinical trials (www.clinicaltrials.gov) investigating the neuroprotective potential of RIC in a wide variety of clinical settings including pediatric and adult cardiac surgery.

\section{Remote ischemic conditioning and other organs and tissues}

\subsection{Remote ischemic conditioning and the gastrointestinal system}

The intestine, stomach and pancreas are all vulnerable to the detrimental effects of acute IRI. Of these the intestine is most commonly affected by acute IRI in a number of clinical settings including cardiac arrest ${ }^{60}$, hemorrhagic shock ${ }^{61}$, burn trauma ${ }^{62}$, and major vascular and cardiac surgery ${ }^{63-65}$, the effects of which are increased intestinal epithelial barrier permeability and translocation of pathogenic bacteria and endotoxins ${ }^{66}$ with subsequent inflammation, sepsis and multi-organ failure ${ }^{67}$.

In 2002, Dickson et al ${ }^{68}$ were the first to report that RIC of the rabbit heart could protect jejunal intestinal contractile function, beneficial effects which were blocked in the presence of either naloxone or glibenclamide, thereby implicating possible involvement of opioids and the $\mathrm{K}_{\mathrm{ATP}}$ channel, known mediators of cardioprotection. Saeki et al ${ }^{69}$ went on to demonstrate that RIC (15 minute infrarenal aortic occlusion and reflow) could protect against intestinal IRI in rats receiving small bowel transplantation. Interestingly, Zitta et al ${ }^{70}$ demonstrated that serum from human volunteers treated with RIC (four-5 minute cycles of arm ischemia and reperfusion) protected intestinal cells against simulated $|R|$ via matrixmetalloproteinase (MMP)-2 and MMP-9. Brzozowski et al ${ }^{71}$ were the first to demonstrate that RIC (two-5 min cycles of myocardial or hepatic ischemia and 
reperfusion) could protect the stomach against acute IRI. RIC gastric protection was found to be abrogated in capsaicin-denervated or vagotomised rats.

Combined pancreas-kidney transplantation has recently been successfully implemented for patients with type 1 diabetes and end-stage renal failure ${ }^{72}$. This operation can be complicated by graft pancreatitis, a contributing factor of which is acute $I R I$, resulting in graft loss ${ }^{73}$. Oehmann et al ${ }^{74}$ were the first to demonstrate that RIC (15 minutes of infrarenal aortic ischemia and reperfusion) could protect the pancreas against acute $\mid \mathrm{RI}$ as evidenced by improved circulation, reduced inflammatory tissue response and histology damage. RIC-mediated protection against acute pancreatic IRI has been confirmed by a subsequent study ${ }^{75}$, although not all studies have been positive ${ }^{76}$.

In terms of clinical application, a large randomised controlled clinical trial is underway investigating the effect of RIC on clinical outcomes following combined liver, kidney or pancreas transplantation (ClinicalTrials.gov identifier: NCT00975702).

\subsection{Remote ischemic conditioning and skin flaps}

In the setting of trauma, plastic and reconstructive surgery, soft tissue coverage is usually performed with the use of local or free skin flaps, a surgical procedure which is associated with significant morbidity due to the risk of necrosis of the implanted flap in $1-5 \%$ of cases ${ }^{77,78}$. This is likely to be caused by prolonged post-operative flap ischemia when the flap is exposed to during the surgery. Küntscher et al ${ }^{79-81}$ were the first to demonstrate that hindlimb RIC (10 min clamping of femoral artery) could protect muscle flaps against IRI. Whether, this RIC is beneficial in the clinical setting of plastic surgery is currently being tested in patients undergoing skin flap transplantation to the anterolateral thigh (ClinicalTrials.gov identifier: NCT01235286). 
It is interesting to note that upper arm RIC has been recently demonstrated to improve cutaneous tissue oxygen saturation, arterial capillary blood flow and postcapillary venous filling pressure in the skin of the contralateral thigh in human volunteers $^{82}$.

\subsection{Remote ischemic conditioning and the ovaries}

Ovarian auto-transplantation is an increasingly used procedure for maintaining fertility in women receiving cytotoxic treatment for malignant disease or immunosuppressive disorders, which ultimately cause early ovary failure ${ }^{83,84}$. This has been observed in up to $34 \%$ of women receiving chemotherapy and $92 \%$ of patients having radio- or chemo-therapy for bone marrow transplantation ${ }^{85}$. Acute IRI of the graft ovary is one of the major factors responsible for preventing graft revascularization and success of ovarian transplantation ${ }^{86}$. It has been demonstrated that hindlimb RIC in the rat improves ovarian viability, vascularization and vasodilatation, findings which were associated with increased serum oestradiol levels, improved graft morphology and follicular maturity ${ }^{87,88}$. This novel application of RIC in improving the success of ovarian transplantation remains to be explored in the clinical setting.

\section{Conclusions}

Although remote ischemic conditioning (RIC) was first discovered as a non-invasive therapeutic strategy for protecting the heart from a distance, its potential for conferring widespread protection against acute $I R I$ in a number of different noncardiac organs and tissues has now been realized. Experimental studies have demonstrated beneficial effects of RIC against acute IRI in a wide variety of organs 
and tissues including kidney, liver, brain, skin flaps, ovaries, intestine, stomach and the pancreas. Further study is now needed to characterize the optimal RIC protocol in terms of efficacy and to elucidate the mechanisms underlying its protective effect. The ability to induce RIC by simply applying the protective stimulus to the arm or leg has facilitated it translation into a number of clinical settings in which vital organs such as the kidney, brain and liver are vulnerable to acute IRI. Large multi-centre randomized controlled clinical trials are needed to investigate whether RIC can improve clinical outcomes in patients at risk of IRI-induced organ and tissue dysfunction.

\section{Funding}

This work was supported by the British Heart Foundation grant number FS/06/023. This work was undertaken at UCLH/UCL who received a proportion of funding from the Department of Health's NIHR Biomedical Research Centres funding scheme.

\section{Conflicts of interest}

None to disclose. 


\section{$\underline{\text { References }}$}

1. Przyklenk K, Bauer B, Ovize M, Kloner RA, Whittaker P. Regional ischemic 'preconditioning' protects remote virgin myocardium from subsequent sustained coronary occlusion. Circulation. 1993;87:893-899

2. Whittaker P, Przyklenk K. Reduction of infarct size in vivo with ischemic preconditioning: Mathematical evidence for protection via non-ischemic tissue. Basic Res Cardiol. 1994;89:615

3. Murry CE, Jennings RB, Reimer KA. Preconditioning with ischemia: A delay of lethal cell injury in ischemic myocardium. Circulation. 1986;74:1124-1136

4. Yellon DM, Downey JM. Preconditioning the myocardium: From cellular physiology to clinical cardiology. Physiol Rev. 2003;83:1113-1151

5. Heusch G. Nitroglycerin and delayed preconditioning in humans: Yet another new mechanism for an old drug? Circulation. 2001;103:2876-2878

6. Zhao ZQ, Corvera JS, Halkos ME, Kerendi F, Wang NP, Guyton RA, Vinten-Johansen J. Inhibition of myocardial injury by ischemic postconditioning during reperfusion: Comparison with ischemic preconditioning. Am J Physiol. 2003;285:H579-588

7. Heusch G. Reduction of infarct size by ischaemic post-conditioning in humans: Fact or fiction? Eur Heart J. 2012;33:13-15

8. McClanahan TB NB, Wolke L, Martin BJ, Mezt TE. Brief renal occlusion and reperfusion reduces myocardial infarct size in rabbits. FASEB J. 1993;7

9. Birnbaum $\mathrm{Y}$, Hale SL, Kloner RA. Ischemic preconditioning at a distance: Reduction of myocardial infarct size by partial reduction of blood supply combined with rapid stimulation of the gastrocnemius muscle in the rabbit. Circulation. 1997;96:1641-1646

10. Oxman T, Arad M, Klein R, Avazov N, Rabinowitz B. Limb ischemia preconditions the heart against reperfusion tachyarrhythmia. Am J Physiol. 1997;273:H1707-1712 
11. Gunaydin B, Cakici I, Soncul H, Kalaycioglu S, Cevik C, Sancak B, Kanzik I, Karadenizli Y. Does remote organ ischaemia trigger cardiac preconditioning during coronary artery surgery? Pharmacol Res. 2000;41:493-496

12. Kharbanda RK, Mortensen UM, White PA, Kristiansen SB, Schmidt MR, Hoschtitzky JA, Vogel M, Sorensen K, Redington AN, MacAllister R. Transient limb ischemia induces remote ischemic preconditioning in vivo. Circulation. 2002;106:2881-2883

13. Schmidt MR, Smerup M, Konstantinov IE, Shimizu M, Li J, Cheung M, White PA, Kristiansen SB, Sorensen K, Dzavik V, Redington AN, Kharbanda RK. Intermittent peripheral tissue ischemia during coronary ischemia reduces myocardial infarction through a katp-dependent mechanism: First demonstration of remote ischemic perconditioning. Am J Physiol. 2007;292:H1883-1890

14. Kerendi F, Kin H, Halkos ME, Jiang R, Zatta AJ, Zhao ZQ, Guyton RA, Vinten-Johansen J. Remote postconditioning. Brief renal ischemia and reperfusion applied before coronary artery reperfusion reduces myocardial infarct size via endogenous activation of adenosine receptors. Basic Res Cardiol. 2005;100:404-412

15. Andreka G, Vertesaljai M, Szantho G, Font G, Piroth Z, Fontos G, Juhasz ED, Szekely L, Szelid Z, Turner MS, Ashrafian H, Frenneaux MP, Andreka P. Remote ischaemic postconditioning protects the heart during acute myocardial infarction in pigs. Heart. 2007;93:749-752

16. Rosner $\mathrm{MH}$, Okusa MD. Acute kidney injury associated with cardiac surgery. CJASN. $2006 ; 1: 19-32$

17. Chertow GM, Levy EM, Hammermeister KE, Grover F, Daley J. Independent association between acute renal failure and mortality following cardiac surgery. Am J Med. $1998 ; 104: 343-348$

18. Wald R, Waikar SS, Liangos O, Pereira BJ, Chertow GM, Jaber BL. Acute renal failure after endovascular vs open repair of abdominal aortic aneurysm. J Vasc Surg. 2006;43:460-466; discussion 466 
19. Diehl JT, Cali RF, Hertzer NR, Beven EG. Complications of abdominal aortic reconstruction. An analysis of perioperative risk factors in 557 patients. Ann Surg. 1983;197:49-56

20. Aronson S, Blumenthal R. Perioperative renal dysfunction and cardiovascular anesthesia: Concerns and controversies. J Cardiothorac Vasc Anesth. 1998;12:567-586

21. Wever KE, Menting TP, Rovers M, van der Vliet JA, Rongen GA, Masereeuw R, RitskesHoitinga $M$, Hooijmans $C R$, Warle $M$. Ischemic preconditioning in the animal kidney, a systematic review and meta-analysis. PloS one. 2012;7:e32296

22. Wever KE, Warle MC, Wagener FA, van der Hoorn JW, Masereeuw R, van der Vliet JA, Rongen GA. Remote ischaemic preconditioning by brief hind limb ischaemia protects against renal ischaemia-reperfusion injury: The role of adenosine. Nephrol Dial Transplant. 2011;26:3108-3117

23. Kadkhodaee M, Seifi B, Najafi A, Sedaghat Z. First report of the protective effects of remote per- and postconditioning on ischemia/reperfusion-induced renal injury. Transplantation. 2011;92:e55

24. Wever KE, Menting T, Masereeuw R, van der Vliet JA, Rongen GA, Warle MC. Local and remote ischemic postconditionings have synergistic protective effects on renal ischemiareperfusion injury. Transplantation. 2012;94:e1-2

25. Ovize M, Baxter GF, Di Lisa F, Ferdinandy P, Garcia-Dorado D, Hausenloy DJ, Heusch G, Vinten-Johansen J, Yellon DM, Schulz R, Working Group of Cellular Biology of Heart of European Society of C. Postconditioning and protection from reperfusion injury: Where do we stand? Position paper from the working group of cellular biology of the heart of the european society of cardiology. Cardiovasc Res. 2010;87:406-423

26. Ludman AJ, Yellon DM, Hausenloy DJ. Cardiac preconditioning for ischaemia: Lost in translation. Dis Mod Mech. 2010;3:35-38

27. Schwartz Longacre L, Kloner RA, Arai AE, Baines CP, Bolli R, Braunwald E, Downey J, Gibbons RJ, Gottlieb RA, Heusch G, Jennings RB, Lefer DJ, Mentzer RM, Murphy E, Ovize M, Ping P, 
Przyklenk K, Sack MN, Vander Heide RS, Vinten-Johansen J, Yellon DM, National Heart L, Blood Institute NloH. New horizons in cardioprotection: Recommendations from the 2010 national heart, lung, and blood institute workshop. Circulation. 2011;124:1172-1179

28. Hausenloy DJ, Baxter G, Bell R, Botker HE, Davidson SM, Downey J, Heusch G, Kitakaze M, Lecour S, Mentzer R, Mocanu MM, Ovize M, Schulz R, Shannon R, Walker M, Walkinshaw G, Yellon DM. Translating novel strategies for cardioprotection: The hatter workshop recommendations. Basic Res Cardiol. 2010;105:677-686

29. Er F, Nia AM, Dopp H, Hellmich M, Dahlem KM, Caglayan E, Kubacki T, Benzing T, Erdmann E, Burst V, Gassanov N. Ischemic preconditioning for prevention of contrast medium-induced nephropathy: Randomized pilot renpro trial (renal protection trial). Circulation. 2012;126:296-303

30. Hausenloy DJ, Candilio L, Laing C, Kunst G, Pepper J, Kolvekar S, Evans R, Robertson S, Knight R, Ariti C, Clayton T, Yellon DM, Investigators ET. Effect of remote ischemic preconditioning on clinical outcomes in patients undergoing coronary artery bypass graft surgery (ericca): Rationale and study design of a multi-centre randomized double-blinded controlled clinical trial. Clin Res Cardiol. 2012;101:339-348

31. Suzuki T. Additional lung-protective perfusion techniques during cardiopulmonary bypass. Ann Thorac Cardiovasc Surg. 2010;16:150-155

32. Kirklin JK, Blackstone EH, Kirklin JW, McKay R, Pacifico AD, Bargeron LM, Jr. Intracardiac surgery in infants under age 3 months: Incremental risk factors for hospital mortality. Am J Cardiol. 1981;48:500-506

33. Kirklin JK, Westaby S, Blackstone EH, Kirklin JW, Chenoweth DE, Pacifico AD. Complement and the damaging effects of cardiopulmonary bypass. J Thorac Cardiovasc Surg. $1983 ; 86: 845-857$

34. Peralta C, Fernandez L, Panes J, Prats N, Sans M, Pique JM, Gelpi E, Rosello-Catafau J. Preconditioning protects against systemic disorders associated with hepatic ischemia- 
reperfusion through blockade of tumor necrosis factor-induced p-selectin up-regulation in the rat. Hepatology. 2001;33:100-113

35. Li G, Chen S, Lu E, Luo W. Cardiac ischemic preconditioning improves lung preservation in valve replacement operations. Ann Thorac Surg. 2001;71:631-635

36. Kooby DA, Fong Y, Suriawinata A, Gonen M, Allen PJ, Klimstra DS, DeMatteo RP, D'Angelica M, Blumgart LH, Jarnagin WR. Impact of steatosis on perioperative outcome following hepatic resection. J Gastrointest Surg. 2003;7:1034-1044

37. Chok KS, Ng KK, Poon RT, Lo CM, Fan ST. Impact of postoperative complications on long-term outcome of curative resection for hepatocellular carcinoma. Br J Surg. 2009;96:81-87

38. Belghiti J, Noun R, Malafosse R, Jagot P, Sauvanet A, Pierangeli F, Marty J, Farges $O$. Continuous versus intermittent portal triad clamping for liver resection: A controlled study. Ann Surg. 1999;229:369-375

39. Chouker A, Schachtner T, Schauer R, Dugas M, Lohe F, Martignoni A, Pollwein B, Niklas M, Rau HG, Jauch KW, Peter K, Thiel M. Effects of pringle manoeuvre and ischaemic preconditioning on haemodynamic stability in patients undergoing elective hepatectomy: A randomized trial. Br J Anaesth. 2004;93:204-211

40. Lai IR, Chang KJ, Chen CF, Tsai HW. Transient limb ischemia induces remote preconditioning in liver among rats: The protective role of heme oxygenase-1. Transplantation. 2006;81:1311-1317

41. Wang F, Birch SE, He R, Tawadros P, Szaszi K, Kapus A, Rotstein OD. Remote ischemic preconditioning by hindlimb occlusion prevents liver ischemic/reperfusion injury: The role of high mobility group-box 1. Ann Surg. 2010;251:292-299

42. Abu-Amara M, Yang SY, Quaglia A, Rowley P, Fuller B, Seifalian A, Davidson B. Role of endothelial nitric oxide synthase in remote ischemic preconditioning of the mouse liver. Liver transpl. 2011;17:610-619 
43. Abu-Amara M, Yang SY, Quaglia A, Rowley P, Tapuria N, Fuller B, Davidson B, Seifalian A. The hepatic soluble guanylyl cyclase-cyclic guanosine monophosphate pathway mediates the protection of remote ischemic preconditioning on the microcirculation in liver ischemiareperfusion injury. Transplantation. 2012;93:880-886

44. Wang $M$, Shen J, Feng B, Gui L, Chen Q, Zhang B, Tang J, Li X. Remote ischemic preconditioning promotes early liver cell proliferation in a rat model of small-for-size liver transplantation. J Surg Res. 2012

45. Donnan GA, Fisher M, Macleod M, Davis SM. Stroke. Lancet. 2008;371:1612-1623

46. Johnston SC, Mendis S, Mathers CD. Global variation in stroke burden and mortality: Estimates from monitoring, surveillance, and modelling. Lancet Neurol. 2009;8:345-354

47. Brott TG, Hobson RW, 2nd, Howard G, Roubin GS, Clark WM, Brooks W, Mackey A, Hill MD, Leimgruber PP, Sheffet AJ, Howard VJ, Moore WS, Voeks JH, Hopkins LN, Cutlip DE, Cohen DJ, Popma JJ, Ferguson RD, Cohen SN, Blackshear JL, Silver FL, Mohr JP, Lal BK, Meschia JF, Investigators C. Stenting versus endarterectomy for treatment of carotid-artery stenosis. $\mathrm{N}$ Eng J Med. 2010;363:11-23

48. Goldstein LB, Adams R, Alberts MJ, Appel LJ, Brass LM, Bushnell CD, Culebras A, Degraba TJ, Gorelick PB, Guyton JR, Hart RG, Howard G, Kelly-Hayes M, Nixon JV, Sacco RL, American Heart Association/American Stroke Association Stroke C, Atherosclerotic Peripheral Vascular Disease Interdisciplinary Working G, Cardiovascular Nursing C, Clinical Cardiology C, Nutrition PA, Metabolism C, Quality of C, Outcomes Research Interdisciplinary Working G, American Academy of N. Primary prevention of ischemic stroke: A guideline from the american heart association/american stroke association stroke council: Cosponsored by the atherosclerotic peripheral vascular disease interdisciplinary working group; cardiovascular nursing council; clinical cardiology council; nutrition, physical activity, and metabolism council; and the quality of care and outcomes research interdisciplinary working group: The 
american academy of neurology affirms the value of this guideline. Stroke. 2006;37:15831633

49. Adams RJ, Albers G, Alberts MJ, Benavente O, Furie K, Goldstein LB, Gorelick P, Halperin J, Harbaugh R, Johnston SC, Katzan I, Kelly-Hayes M, Kenton EJ, Marks M, Sacco RL, Schwamm LH, American Heart A, American Stroke A. Update to the aha/asa recommendations for the prevention of stroke in patients with stroke and transient ischemic attack. Stroke. 2008;39:1647-1652

50. Ederle J, Featherstone RL, Brown MM. Percutaneous transluminal angioplasty and stenting for carotid artery stenosis. Cochrane Database Syst Rev. 2007:CD000515

51. Greenstein AJ, Chassin MR, Wang J, Rockman CB, Riles TS, Tuhrim S, Halm EA. Association between minor and major surgical complications after carotid endarterectomy: Results of the new york carotid artery surgery study. J Vasc Surg. 2007;46:1138-1144; discussion 11451136

52. Dellagrammaticas D, Lewis S, Colam B, Rothwell PM, Warlow CP, Gough MJ, collaborators Gt. Carotid endarterectomy in the uk: Acceptable risks but unacceptable delays. Clin Med. $2007 ; 7: 589-592$

53. Dave KR, Saul I, Prado R, Busto R, Perez-Pinzon MA. Remote organ ischemic preconditioning protect brain from ischemic damage following asphyxial cardiac arrest. Neurosci Lett. 2006;404:170-175

54. Ren C, Yan Z, Wei D, Gao X, Chen X, Zhao H. Limb remote ischemic postconditioning protects against focal ischemia in rats. Brain Res. 2009;1288:88-94

55. Roubille F, Franck-Miclo A, Covinhes A, Lafont C, Cransac F, Combes S, Vincent A, Fontanaud P, Sportouch-Dukhan C, Redt-Clouet C, Nargeot J, Piot C, Barrere-Lemaire S. Delayed postconditioning in the mouse heart in vivo. Circulation. 2011;124:1330-1336 
56. Koch S, Katsnelson M, Dong C, Perez-Pinzon M. Remote ischemic limb preconditioning after subarachnoid hemorrhage: A phase ib study of safety and feasibility. Stroke. 2011;42:13871391

57. Hu S, Dong HL, Li YZ, Luo ZJ, Sun L, Yang QZ, Yang LF, Xiong L. Effects of remote ischemic preconditioning on biochemical markers and neurologic outcomes in patients undergoing elective cervical decompression surgery: A prospective randomized controlled trial. J Neur Anesth. 2010;22:46-52

58. Walsh SR, Nouraei SA, Tang TY, Sadat U, Carpenter RH, Gaunt ME. Remote ischemic preconditioning for cerebral and cardiac protection during carotid endarterectomy: Results from a pilot randomized clinical trial. Vasc Endovascular Surg. 2010;44:434-439

59. Hougaard KD, Hjort N, Zeidler D, Sorensen L, Norgaard A, Thomsen RB, Jonsdottir K, Mouridsen K, Hansen TM, Cho TH, Nielsen TT, Botker HE, Ostergaard L, Andersen G. Remote ischemic perconditioning in thrombolysed stroke patients: Randomized study of activating endogenous neuroprotection - design and mri measurements. Int J Stroke. 2012

60. Korth U, Krieter H, Denz C, Janke C, Ellinger K, Bertsch T, Henn C, Klein J. Intestinal ischaemia during cardiac arrest and resuscitation: Comparative analysis of extracellular metabolites by microdialysis. Resuscitation. 2003;58:209-217

61. Rupani B, Caputo FJ, Watkins AC, Vega D, Magnotti LJ, Lu Q, Xu da Z, Deitch EA. Relationship between disruption of the unstirred mucus layer and intestinal restitution in loss of gut barrier function after trauma hemorrhagic shock. Surgery. 2007;141:481-489

62. Epstein MD, Tchervenkov JI, Alexander JW, Johnson JR, Vester JW. Increased gut permeability following burn trauma. Arch Surg. 1991;126:198-200

63. Roumen RM, van der Vliet JA, Wevers RA, Goris RJ. Intestinal permeability is increased after major vascular surgery. J Vasc Surg. 1993;17:734-737

64. Chaudhuri N, James J, Sheikh A, Grayson AD, Fabri BM. Intestinal ischaemia following cardiac surgery: A multivariate risk model. Eur J Cardiothorac Surg. 2006;29:971-977 
65. Oudemans-van Straaten HM, Jansen PG, Hoek FJ, van Deventer SJ, Sturk A, Stoutenbeek CP, Tytgat GN, Wildevuur CR, Eysman L. Intestinal permeability, circulating endotoxin, and postoperative systemic responses in cardiac surgery patients. J Cardiothorac Vasc Anesth. 1996;10:187-194

66. Magnotti $\amalg$, Deitch EA. Burns, bacterial translocation, gut barrier function, and failure. J Burn Care Rehabil. 2005;26:383-391

67. Swank GM, Deitch EA. Role of the gut in multiple organ failure: Bacterial translocation and permeability changes. World J Surg. 1996;20:411-417

68. Dickson EW, Tubbs RJ, Porcaro WA, Lee WJ, Blehar DJ, Carraway RE, Darling CE, Przyklenk K. Myocardial preconditioning factors evoke mesenteric ischemic tolerance via opioid receptors and k(atp) channels. Am J Physiol. 2002;283:H22-28

69. Saeki I, Matsuura T, Hayashida M, Taguchi T. Ischemic preconditioning and remote ischemic preconditioning have protective effect against cold ischemia-reperfusion injury of rat small intestine. Pediatr Surg Int. 2011;27:857-862

70. Zitta K, Meybohm P, Bein B, Heinrich C, Renner J, Cremer J, Steinfath M, Scholz J, Albrecht M. Serum from patients undergoing remote ischemic preconditioning protects cultured human intestinal cells from hypoxia-induced damage: Involvement of matrixmetalloproteinase-2 and -9. Mol Med. 2012;18:29-37

71. Brzozowski T, Konturek PC, Pajdo R, Kwiecien S, Sliwowski Z, Drozdowicz D, Ptak-Belowska A, Pawlik M, Konturek SJ, Pawlik WW, Hahn GG. Importance of brain-gut axis in the gastroprotection induced by gastric and remote preconditioning. J Physiol Pharmacol. 2004;55:165-177

72. Wynn JJ, Distant DA, Pirsch JD, Norman D, Gaber AO, Ashby VB, Leichtman AB. Kidney and pancreas transplantation. Am J Transplant. 2004;4 Suppl 9:72-80

73. Busing M, Hopt UT, Quacken M, Becker HD, Morgenroth K. Morphological studies of graft pancreatitis following pancreas transplantation. Br J Surg. 1993;80:1170-1173 
74. Oehmann C, Benz S, Drognitz O, Pisarski P, Hopt UT, Obermaier R. Remote preconditioning reduces microcirculatory disorders in pancreatic ischemia/reperfusion injury. Pancreas. 2007;35:e45-50

75. Nikeghbalian S, Mansoorian MR, Hosseini SM, Mardani P, Geramizadeh B, Hosseini SA. Reduction of the severity of ischemia reperfusion-induced pancreatitis by ischemic preconditioning of the liver. Saudi J Kidney Dis Transpl. 2009;20:1010-1014

76. Warzecha Z, Dembinski A, Ceranowicz P, Cieszkowski J, Konturek SJ, Dembinski M, KusnierzCabala B, Tomaszewska R, Pawlik WW. Ischemic preconditioning of the hindlimb or kidney does not attenuate the severity of acute ischemia/reperfusion-induced pancreatitis in rats. $J$ Physiol Pharmacol. 2008;59:337-352

77. Lorenzo AR, Lin CH, Lin CH, Lin YT, Nguyen A, Hsu CC, Wei FC. Selection of the recipient vein in microvascular flap reconstruction of the lower extremity: Analysis of 362 free-tissue transfers. J PlastReconstr Aesthet Surg. 2011;64:649-655

78. Nahabedian MY, Momen B, Manson PN. Factors associated with anastomotic failure after microvascular reconstruction of the breast. Plast Reconstr Surg. 2004;114:74-82

79. Kuntscher MV, Kastell T, Sauerbier M, Nobiling R, Gebhard MM, Germann G. Acute remote ischemic preconditioning on a rat cremasteric muscle flap model. Microsurgery. 2002;22:221-226

80. Kuntscher MV, Schirmbeck EU, Menke H, Klar E, Gebhard MM, Germann G. Ischemic preconditioning by brief extremity ischemia before flap ischemia in a rat model. Plast Reconstr Surg. 2002;109:2398-2404

81. Kuntscher MV, Kastell T, Engel H, Gebhard MM, Heitmann C, Germann G. Late remote ischemic preconditioning in rat muscle and adipocutaneous flap models. Ann Plastic Surg. 2003;51:84-90 
82. Kraemer R, Lorenzen J, Kabbani M, Herold C, Busche M, Vogt PM, Knobloch K. Acute effects of remote ischemic preconditioning on cutaneous microcirculation--a controlled prospective cohort study. BMC surgery. 2011;11:32

83. Donnez J, Squifflet J, Dolmans MM, Martinez-Madrid B, Jadoul P, Van Langendonckt A. Orthotopic transplantation of fresh ovarian cortex: A report of two cases. Fertil Steril. $2005 ; 84: 1018$

84. Mhatre P, Mhatre J, Magotra R. Ovarian transplant: A new frontier. Transplant Proc. 2005;37:1396-1398

85. Meirow D, Fasouliotis SJ, Nugent D, Schenker JG, Gosden RG, Rutherford AJ. A laparoscopic technique for obtaining ovarian cortical biopsy specimens for fertility conservation in patients with cancer. Fertil Steril. 1999;71:948-951

86. Liu J, Van der Elst J, Van den Broecke R, Dhont M. Early massive follicle loss and apoptosis in heterotopically grafted newborn mouse ovaries. Hum Reprod. 2002;17:605-611

87. Damous LL, Silva SM, Simoes RS, Morello RJ, Carbonel AP, Simoes MJ, Montero EF. Remote ischemic preconditioning on neovascularization and follicle viability on ovary autotransplantation in rats. Transplant Proc. 2008;40:861-864

88. Damous LL, Silva SM, Carbonel AP, Simoes RS, Simoes MJ, Montero EF. Effect of remote ischemic preconditioning on rat estradiol serum levels and follicular development after ovarian transplantation. Transplant Proc. 2009;41:830-833

89. Ates E, Genc E, Erkasap N, Erkasap S, Akman S, Firat P, Emre S, Kiper H. Renal protection by brief liver ischemia in rats. Transplantation. 2002;74:1247-1251

90. Song T, Peng YF, Guo SY, Liu YH, Liul LY. Brief small intestinal ischemia lessens renal ischemia-reperfusion injury in rats. Comp Med.2007;57:200-205

91. Lazaris AM, Maheras AN, Vasdekis SN, Karkaletsis KG, Charalambopoulos A, Kakisis JD, Martikos G, Patapis P, Giamarellos-Bourboulis EJ, Karatzas GM, Liakakos TD. Protective 
effect of remote ischemic preconditioning in renal ischemia/reperfusion injury, in a model of thoracoabdominal aorta approach. J Surg Res. 2009;154:267-273

92. Ali ZA, Callaghan CJ, Lim E, Ali AA, Nouraei SA, Akthar AM, Boyle JR, Varty K, Kharbanda RK, Dutka DP, Gaunt ME. Remote ischemic preconditioning reduces myocardial and renal injury after elective abdominal aortic aneurysm repair: A randomized controlled trial. Circulation. 2007;116:198-105

93. Walsh SR, Boyle JR, Tang TY, Sadat U, Cooper DG, Lapsley M, Norden AG, Varty K, Hayes PD, Gaunt ME. Remote ischemic preconditioning for renal and cardiac protection during endovascular aneurysm repair: A randomized controlled trial. J Endovasc Ther. 2009;16:680689

94. Walsh SR, Sadat U, Boyle JR, Tang TY, Lapsley M, Norden AG, Gaunt ME. Remote ischemic preconditioning for renal protection during elective open infrarenal abdominal aortic aneurysm repair: Randomized controlled trial. Vasc Endovasc Surg. 2010;44:334-340

95. Venugopal V, Laing CM, Ludman A, Yellon DM, Hausenloy D. Effect of remote ischemic preconditioning on acute kidney injury in nondiabetic patients undergoing coronary artery bypass graft surgery: A secondary analysis of 2 small randomized trials. Am J Kidney Dis. 2010;56:1043-1049

96. Thielmann M, Kottenberg E, Boengler K, Raffelsieper C, Neuhaeuser M, Peters J, Jakob H, Heusch G. Remote ischemic preconditioning reduces myocardial injury after coronary artery bypass surgery with crystalloid cardioplegic arrest. Basic Res Cardiol. 2010;105:657-664

97. Rahman IA, Mascaro JG, Steeds RP, Frenneaux MP, Nightingale P, Gosling P, Townsend P, Townend JN, Green D, Bonser RS. Remote ischemic preconditioning in human coronary artery bypass surgery: From promise to disappointment? Circulation. 2010;122:S53-59

98. Choi YS, Shim JK, Kim JC, Kang KS, Seo YH, Ahn KR, Kwak YL. Effect of remote ischemic preconditioning on renal dysfunction after complex valvular heart surgery: A randomized controlled trial. J Thorac Cardiovasc Surg. 2011;142:148-154 
99. Zimmerman RF, Ezeanuna PU, Kane JC, Cleland CD, Kempananjappa TJ, Lucas FL, Kramer RS. Ischemic preconditioning at a remote site prevents acute kidney injury in patients following cardiac surgery. Kidney Int. 2011;80:861-867

100. Pedersen KR, Ravn HB, Povlsen JV, Schmidt MR, Erlandsen EJ, Hjortdal VE. Failure of remote ischemic preconditioning to reduce the risk of postoperative acute kidney injury in children undergoing operation for complex congenital heart disease: A randomized single-center study. J Thorac Cardiovasc Surg. 2012;143:576-583

101. Whittaker P, Przyklenk K. Remote-conditioning ischemia provides a potential approach to mitigate contrast medium-induced reduction in kidney function: A retrospective observational cohort study. Cardiology. 2011;119:145-150

102. Hong DM, Jeon Y, Lee CS, Kim HJ, Lee JM, Bahk JH, Kim KB, Hwang HY. Effects of remote ischemic preconditioning with postconditioning in patients undergoing off-pump coronary artery bypass surgery--randomized controlled trial. Circ J. 2012;76:884-890

103. Harkin DW, Barros D'Sa AA, McCallion K, Hoper M, Campbell FC. Ischemic preconditioning before lower limb ischemia--reperfusion protects against acute lung injury. J Vasc Surg. $2002 ; 35: 1264-1273$

104. Xia Z, Herijgers P, Nishida T, Ozaki S, Wouters P, Flameng W. Remote preconditioning lessens the deterioration of pulmonary function after repeated coronary artery occlusion and reperfusion in sheep. Can J Anaesth. 2003;50:481-488

105. Waldow T, Alexiou K, Witt W, Albrecht S, Wagner F, Knaut M, Matschke K. Protection against acute porcine lung ischemia/reperfusion injury by systemic preconditioning via hind limb ischemia. Transpl Int. 2005;18:198-205

106. Olguner C, Koca U, Kar A, Karci A, Islekel H, Canyilmaz M, Mavioglu O, Kizildag S, Unlu G, Elar Z. Ischemic preconditioning attenuates the lipid peroxidation and remote lung injury in the rat model of unilateral lower limb ischemia reperfusion. Acta anaesthesiol Scand. 2006;50:150-155 
107. Kharbanda RK, Li J, Konstantinov IE, Cheung MM, White PA, Frndova H, Stokoe J, Cox P, Vogel M, Van Arsdell G, MacAllister R, Redington AN. Remote ischaemic preconditioning protects against cardiopulmonary bypass-induced tissue injury: A preclinical study. Heart. 2006;92:1506-1511

108. Cheung MM, Kharbanda RK, Konstantinov IE, Shimizu M, Frndova H, Li J, Holtby HM, Cox PN, Smallhorn JF, Van Arsdell GS, Redington AN. Randomized controlled trial of the effects of remote ischemic preconditioning on children undergoing cardiac surgery: First clinical application in humans. J Am Coll Cardiol. 2006;47:2277-2282

109. Zhou W, Zeng D, Chen R, Liu J, Yang G, Liu P, Zhou X. Limb ischemic preconditioning reduces heart and lung injury after an open heart operation in infants. Pediatr Cardiol. 2010;31:22-29

110. Li L, Luo W, Huang L, Zhang W, Gao Y, Jiang H, Zhang C, Long L, Chen S. Remote perconditioning reduces myocardial injury in adult valve replacement: A randomized controlled trial. J Surg Res. 2010;164:e21-26

111. Lin $L N$, Wang $L R$, Wang $W T$, Jin $L L$, Zhao $X Y$, Zheng $L P$, Jin $L D$, Jiang $L M$, Xiong $X Q$. Ischemic preconditioning attenuates pulmonary dysfunction after unilateral thigh tourniquet-induced ischemia-reperfusion. Anesth Analg. 2010;111:539-543

112. Young PJ, Dalley P, Garden A, Horrocks C, La Flamme A, Mahon B, Miller J, Pilcher J, Weatherall M, Williams J, Young W, Beasley R. A pilot study investigating the effects of remote ischemic preconditioning in high-risk cardiac surgery using a randomised controlled double-blind protocol. Basic Res Cardiol. 2012;107:256

113. Kim JC, Shim JK, Lee S, Yoo YC, Yang SY, Kwak YL. Effect of combined remote ischemic preconditioning and postconditioning on pulmonary function in valvular heart surgery. Chest. 2012

114. Lomivorotov VV, Shmyrev VA, Nepomnyaschih VA, Ponomarev DN, Knyazkova LG, Lomivorotov VN, Karaskov AM. Remote ischaemic preconditioning does not protect the 
heart in patients undergoing coronary artery bypass grafting. Interact Cardiovasc Thorac Surg. 2012;15:18-22

115. Kanoria S, Jalan R, Davies NA, Seifalian AM, Williams R, Davidson BR. Remote ischaemic preconditioning of the hind limb reduces experimental liver warm ischaemia-reperfusion injury. Br J Surg. 2006;93:762-768

116. Gustafsson BI, Friman S, Wallin M, Heiman J, Delbro DS. Effect of remote preconditioning on mild or severe ischemia-reperfusion injury to rat liver. Transplant Proc. 2006;38:2708-2709

117. Tapuria N, Junnarkar SP, Dutt N, Abu-Amara M, Fuller B, Seifalian AM, Davidson BR. Effect of remote ischemic preconditioning on hepatic microcirculation and function in a rat model of hepatic ischemia reperfusion injury. HPB. 2009;11:108-117

118. Abu-Amara M, Yang SY, Quaglia A, Rowley P, de Mel A, Tapuria N, Seifalian A, Davidson B, Fuller B. Nitric oxide is an essential mediator of the protective effects of remote ischaemic preconditioning in a mouse model of liver ischaemia/reperfusion injury. Clin Sci. $2011 ; 121: 257-266$

119. Kanoria S, Glantzounis G, Quaglia A, Dinesh S, Fusai G, Davidson BR, Seifalian AM. Remote preconditioning improves hepatic oxygenation after ischaemia reperfusion injury. Transpl Int. 2012;25:783-791

120. Gurcun U, Discigil B, Boga M, Ozkisacik E, Badak MI, Yenisey C, Kurtoglu T, Meteoglu I. Is remote preconditioning as effective as direct ischemic preconditioning in preventing spinal cord ischemic injury? J Surg Res. 2006;135:385-393

121. Zhao H, Xiong LZ, Dong HL, Chen SY, Lu ZH, Sun YY, Sun J, Gao P. [protective effect of remote ischemic preconditioning against focal cerebral ischemia/reperfusion injury in rats]. Zhongguo wei zhong bing ji jiu yi xue. 2007;19:340-342

122. Rehni AK, Shri R, Singh M. Remote ischaemic preconditioning and prevention of cerebral injury. Indian J Exp Biol. 2007;45:247-252 
123. Ren C, Gao X, Steinberg GK, Zhao H. Limb remote-preconditioning protects against focal ischemia in rats and contradicts the dogma of therapeutic time windows for preconditioning. Neuroscience. 2008;151:1099-1103

124. Saxena P, Bala A, Campbell K, Meloni B, d'Udekem Y, Konstantinov IE. Does remote ischemic preconditioning prevent delayed hippocampal neuronal death following transient global cerebral ischemia in rats? Perfusion. 2009;24:207-211

125. Yannopoulos FS, Makela T, Niemela E, Tuominen H, Lepola P, Alestalo K, Kaakinen H, Kiviluoma K, Anttila V, Juvonen T. Improved cerebral recovery from hypothermic circulatory arrest after remote ischemic preconditioning. Ann Thorac Surg. 2010;90:182-188

126. Xu T, Gong Z, Zhu WZ, Wang JF, Li B, Chen F, Deng XM. Remote ischemic preconditioning protects neurocognitive function of rats following cerebral hypoperfusion. Med Sci Monit. 2011;17:BR299-304

127. Malhotra S, Naggar I, Stewart M, Rosenbaum DM. Neurogenic pathway mediated remote preconditioning protects the brain from transient focal ischemic injury. Brain Res. 2011;1386:184-190

128. Jensen HA, Loukogeorgakis S, Yannopoulos F, Rimpilainen E, Petzold A, Tuominen H, Lepola P, Macallister RJ, Deanfield JE, Makela T, Alestalo K, Kiviluoma K, Anttila V, Tsang V, Juvonen T. Remote ischemic preconditioning protects the brain against injury after hypothermic circulatory arrest. Circulation. 2011;123:714-721

129. Zhou Y, Fathali N, Lekic T, Ostrowski RP, Chen C, Martin RD, Tang J, Zhang JH. Remote limb ischemic postconditioning protects against neonatal hypoxic-ischemic brain injury in rat pups by the opioid receptor/akt pathway. Stroke. 2011;42:439-444

130. Hahn CD, Manlhiot C, Schmidt MR, Nielsen TT, Redington AN. Remote ischemic perconditioning: A novel therapy for acute stroke? Stroke. 2011;42:2960-2962 
131. Sun J, Tong L, Luan Q, Deng J, Li Y, Li Z, Dong H, Xiong L. Protective effect of delayed remote limb ischemic postconditioning: Role of mitochondrial k(atp) channels in a rat model of focal cerebral ischemic reperfusion injury. J Cereb Blood Flow Metab. 2012;32:851-859

132. Geng $X$, Ren $C$, Wang $T$, Fu $P$, Luo $Y$, Liu X, Yan F, Ling F, Jia J, Du H, Ji X, Ding Y. Effect of remote ischemic postconditioning on an intracerebral hemorrhage stroke model in rats. Neurol Res. 2012;34:143-148

133. Wei $\mathrm{D}$, Ren $\mathrm{C}$, Chen $\mathrm{X}$, Zhao $\mathrm{H}$. The chronic protective effects of limb remote preconditioning and the underlying mechanisms involved in inflammatory factors in rat stroke. PloS one. 2012;7:e30892

134. Hu S, Dong H, Zhang H, Wang S, Hou L, Chen S, Zhang J, Xiong L. Noninvasive limb remote ischemic preconditioning contributes neuroprotective effects via activation of adenosine a1 receptor and redox status after transient focal cerebral ischemia in rats. Brain Res. 2012;1459:81-90 


\section{Figure legend}

This figure demonstrates the non-cardiac organs and tissue in which remote ischemic conditioning (RIC, inflations and deflations of a blood pressure cuff placed on the upper arm or thigh to induce cycles of non-lethal ischemia and reperfusion) may offer protection against acute ischemia-reperfusion injury (IRI). In each organ and tissue, there are number of clinical settings in which RIC has been or is currently being investigated as a therapeutic strategy or in which the potential for clinical application exists. 


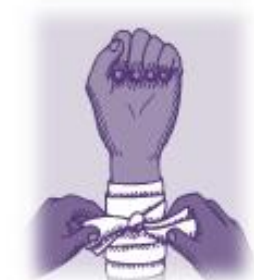

SKIN FLAP

Trauma surgery

Plastic surgery

Reconstructive surgery

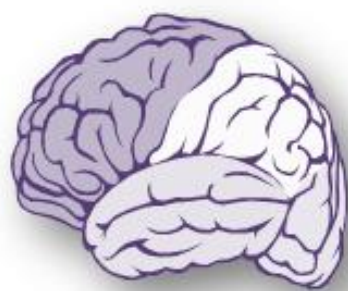

BRAIN

Stroke

Subarachnoid hemorrhage

Carotid endarterectomy Cervical decompression surgery Cerebral asphyxia

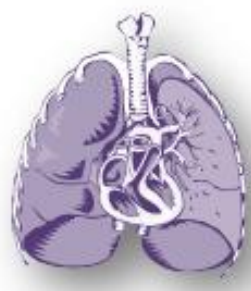

\section{LUNGS}

Resection surgery

Transplantation

Cardiac surgery

Vascular surgery
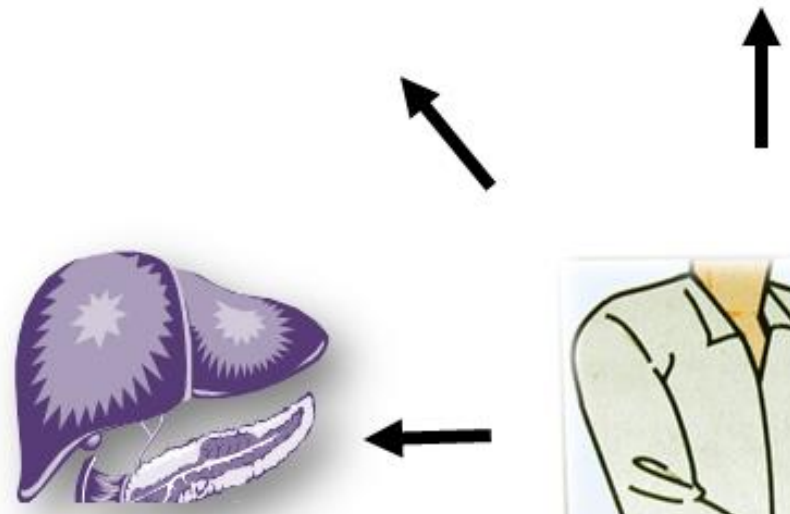

\section{LIVER}

Resection surgery Transplantation
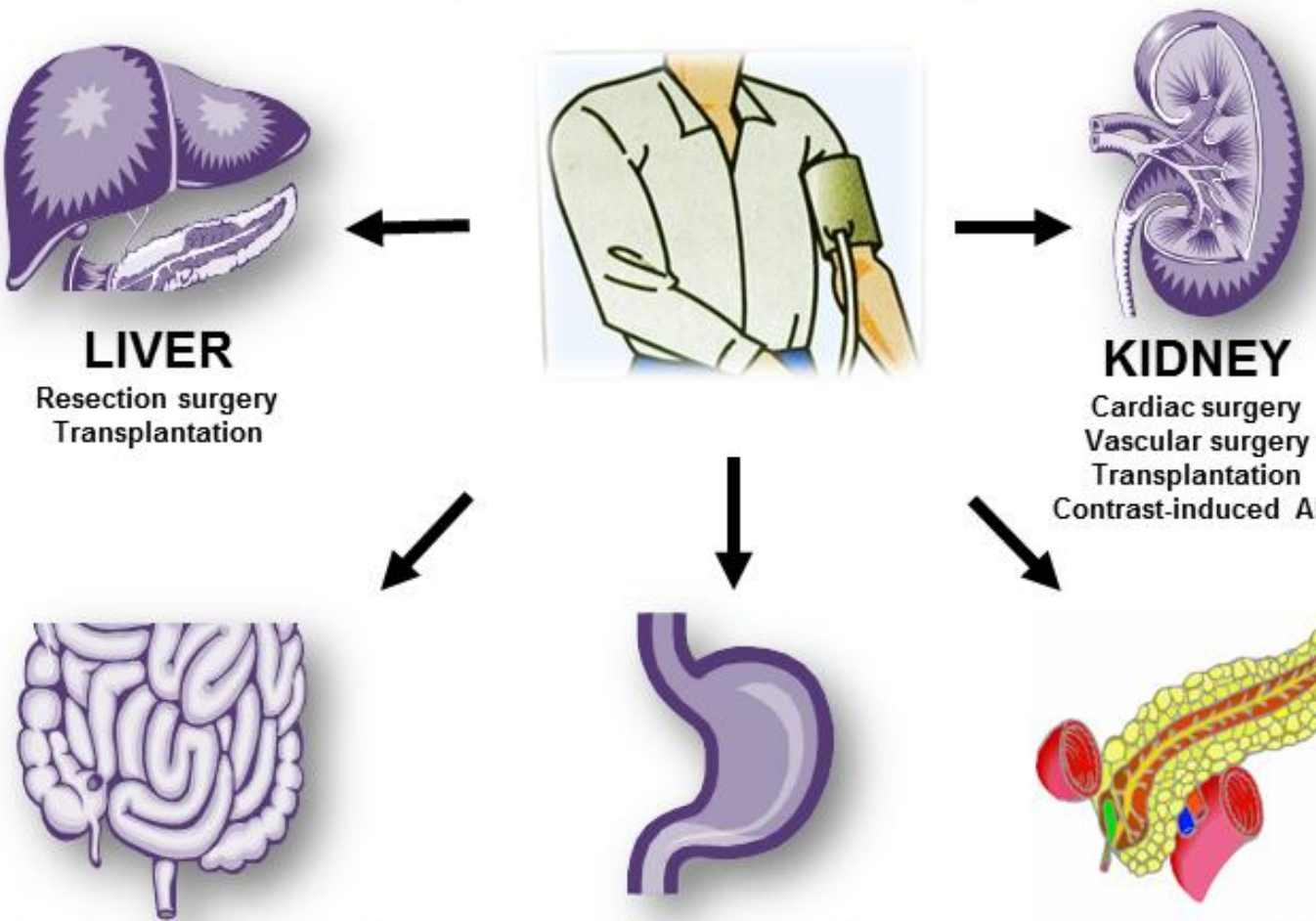

STOMACH

Gastric ischemia

KIDNEY

Cardiac surgery

Vascular surgery

Transplantation

Contrast-induced AKI

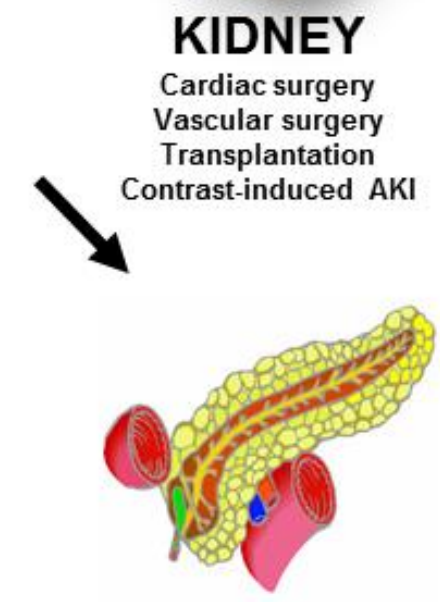

PANCREAS

IRI Pancreatitis

Transplantation 
Table 1a: Major experimental studies investigating the effect of RIC on preventing acute renal IRI

\begin{tabular}{|c|c|c|c|}
\hline $\begin{array}{l}\text { Experimental } \\
\text { study }\end{array}$ & Experimental setting & RIC protocol & Result of RIC \\
\hline Ates et al $2002^{89}$ & $\begin{array}{l}\text { Rat model of renal acute IRI } \\
(45 \mathrm{~min} \mathrm{I} / 24 \mathrm{hr} \mathrm{R})\end{array}$ & $\begin{array}{l}\text { One-10 min cycle of hepatic } \\
\text { IR }\end{array}$ & $\begin{array}{l}\text { Reduced BUN levels at } 24 \text { hours and improved } \\
\text { histological changes. }\end{array}$ \\
\hline Song et al $2007^{90}$ & $\begin{array}{l}\text { Rat model of renal acute IRI } \\
(45 \mathrm{~min} \mathrm{I} / 24 \mathrm{hr} \mathrm{R})\end{array}$ & $\begin{array}{l}\text { Three-cycles of } 8 \mathrm{~min} I \text { and } 5 \\
\text { min R of small intestine }\end{array}$ & $\begin{array}{l}\text { Reduced levels of } \mathrm{Cr}, \mathrm{BUN} \text { and less renal } \\
\text { morphologic change. }\end{array}$ \\
\hline Lazaris et al $2009^{91}$ & $\begin{array}{l}\text { Rat model of renal acute IRI } \\
(45 \text { min aortic cross-clamp/45 } \\
\text { min } R \text { ) }\end{array}$ & $\begin{array}{l}\text { One-15 min cycle of aortic } \\
\text { clamping and declamping }\end{array}$ & $\begin{array}{l}\text { Reduced levels of renal blood lactate and MDA } \\
\text { and less renal tissue MDA. }\end{array}$ \\
\hline $\begin{array}{l}\text { Kadkhodaee et al } \\
2011^{23}\end{array}$ & $\begin{array}{l}\text { Rat model of renal acute IRI } \\
\text { ( } 45 \mathrm{~min} \mathrm{I/24} \mathrm{hr} \mathrm{R)}\end{array}$ & $\begin{array}{l}\text { Four-5 min cycles of IR to one } \\
\text { hindlimb during acute renal } \\
\text { ischemia (RIPerC) and at the } \\
\text { onset of reperfusion (RIPost). }\end{array}$ & Reduced $\mathrm{Cr}$ and BUN levels at 24 hours. \\
\hline Wever et al $2011^{22}$ & $\begin{array}{l}\text { Rat model of renal acute IRI } \\
(25 \text { min I } / 48 \mathrm{hr} \mathrm{R})\end{array}$ & $\begin{array}{l}\text { Four RIC protocols prior to } \\
\text { acute renal IRI: One- } 12 \text { min or } \\
\text { three- } 4 \text { min cycles of IR to one } \\
\text { or both hind-limbs. }\end{array}$ & $\begin{array}{l}\text { All RIC protocols except } 12 \text { min IR to one limb } \\
\text { improved renal function. Protective effect } \\
\text { dependant on tissue mass. }\end{array}$ \\
\hline Wever et al $2012^{24}$ & $\begin{array}{l}\text { Rat model of renal acute IRI } \\
\text { ( } 25 \text { min I /48 hr R) }\end{array}$ & $\begin{array}{l}\text { Three- } 5 \text { min cycles of IR to } \\
\text { both hindlimbs at the onset of } \\
\text { reperfusion (RIPost). }\end{array}$ & $\begin{array}{l}\text { Improved renal function. RIC effect synergistic } \\
\text { with local IPost }\end{array}$ \\
\hline
\end{tabular}

I-ischemia, R-reperfusion, IR-ischemia and reperfusion, IRI-ischemia-reperfusion injury, RIC-remote ischemic conditioning, RIPerC- remote ischemic perconditioning, RIPost- remote ischemic postconditioning, IPost- ischemic postconditioning, BUN-blood urea nitrogen, Cr-creatinine, MDA- malondialdehyde 
Table 1b: Major clinical studies investigating the effect of RIC on preventing acute renal IRI

\begin{tabular}{|c|c|c|c|c|}
\hline Clinical study & Clinical setting & $\mathbf{N}$ & RIC protocol & Result of RIC \\
\hline Ali et al $2007^{92}$ & Elective AAA repair & 82 & $\begin{array}{l}10 \text { min clamping of the right } \\
\text { common iliac artery } \\
\text { followed by clamping of the } \\
\text { left common iliac artery. }\end{array}$ & $\begin{array}{l}23 \% \text { absolute risk reduction in the } \\
\text { incidence of renal impairment (defined as } \\
\text { peak serum Cr level of } 177 \mu \mathrm{mol} / \mathrm{L}(2.0 \\
\mathrm{mg} / \mathrm{dL})) \text {. }\end{array}$ \\
\hline$\underset{93}{\text { Walsh et al } 2009}$ & Elective EVAR & 40 & $\begin{array}{l}\text { 10min cuff inflation of the } \\
\text { right thigh followed by } 10 \\
\text { min cuff inflation of the left } \\
\text { thigh. }\end{array}$ & $\begin{array}{l}\text { Attenuated increase in the renal injury } \\
\text { biomarker, urinary retinol binding protein, } \\
\text { and a non-significant reduction in the } \\
\text { urinary albumin:Cr ratio. }\end{array}$ \\
\hline$\underset{94}{\text { Walsh et al } 2010}$ & Elective open infrarenal AAA repair & 40 & $\begin{array}{l}10 \text { min clamping of the right } \\
\text { common iliac artery } \\
\text { followed by clamping of the } \\
\text { left common iliac artery. }\end{array}$ & $\begin{array}{l}\text { No effect on either urinary retinol binding } \\
\text { or albumin:Cr ratio }\end{array}$ \\
\hline $\begin{array}{l}\text { Venugopal et al } \\
2010^{95}\end{array}$ & Adult CABG surgery & 78 & $\begin{array}{l}\text { Three-5 min upper arm cuff } \\
\text { inflations/deflations }\end{array}$ & $\begin{array}{l}\text { Retrospective study showing a reduction } \\
\text { in the incidence of } \mathrm{AKI} \text { (according to AKIN } \\
\text { criteria) from } 25 \text { to } 11 \% \text {. }\end{array}$ \\
\hline $\begin{array}{l}\text { Thielmann et al } \\
2010^{96}\end{array}$ & Adult CABG surgery & 53 & $\begin{array}{l}\text { Three-5 min upper arm cuff } \\
\text { inflations/deflations }\end{array}$ & $\begin{array}{l}\text { No overall difference in Cr levels and } \\
\text { eGFR over } 72 \text { hrs. } \\
\text { Improved post-operative peak Cr levels in } \\
\text { RIC group } \\
\text { Lower post-operative minimum eGFR in } \\
\text { control group. }\end{array}$ \\
\hline $\begin{array}{l}\text { Rahman et al } \\
2010^{97}\end{array}$ & Adult CABG surgery & 162 & $\begin{array}{l}\text { Three-5 min upper arm cuff } \\
\text { inflations/deflations }\end{array}$ & No effect on AKI or renal biomarkers \\
\hline Choi et al $2011^{98}$ & Adult complex valve surgery & 76 & $\begin{array}{l}\text { Three-10 min thigh cuff } \\
\text { inflations/deflations }\end{array}$ & $\begin{array}{l}\text { No effect on AKI or renal biomarkers } \\
\text { (serum Cr, cystatin C and NGAL). }\end{array}$ \\
\hline $\begin{array}{l}\text { Zimmerman et al } \\
2011\end{array}$ & Adult CABG surgery & 120 & $\begin{array}{l}\text { Three-5 min thigh cuff } \\
\text { inflations/deflations }\end{array}$ & $\begin{array}{l}\text { Reduction from } 47 \% \text { to } 20 \% \text { in the } \\
\text { incidence of } \mathrm{AKI} \text { (defined as an increase } \\
\text { in serum } \mathrm{Cr} \text { levels by at least } 0.3 \mathrm{mg} / \mathrm{dL} \text { or } \\
50 \% \text { more than the baseline value within } \\
48 \mathrm{hr} \text { of surgery). } \\
\text { No difference in plasma NGAL at } 3 \text { hours. }\end{array}$ \\
\hline $\begin{array}{l}\text { Pedersen et al } \\
2011^{100}\end{array}$ & $\begin{array}{l}\text { Paediatric cardiac surgery for } \\
\text { complex congenital heart disease }\end{array}$ & 103 & $\begin{array}{l}\text { Four-5 min thigh cuff } \\
\text { inflations/deflations }\end{array}$ & No effect on AKI or renal biomarkers. \\
\hline $\begin{array}{l}\text { Whittaker et al } \\
2011^{101}\end{array}$ & $\begin{array}{l}\text { Adult patients with mildly impaired } \\
\text { renal function undergoing primary } \\
\mathrm{PCl}\end{array}$ & 43 & $\begin{array}{l}>4 \text { inflations/deflations of } \\
\text { angioplasty balloon }\end{array}$ & $\begin{array}{l}\text { Retrospective study showing preserved } \\
\text { renal function in those receiving } \\
\text { angioplasty balloon inflations/deflations at } \\
\text { time of primary PCl. }\end{array}$ \\
\hline$\underset{102}{\text { Hong et al } 2012}$ & Adult OPCABG surgery & 70 & $\begin{array}{l}\text { Four- } 5 \text { min cycles of thigh } \\
\text { cuff ischemia and } \\
\text { reperfusion prior to after } \\
\text { anastomoses. }\end{array}$ & $\frac{\text { No difference in post-operative renal }}{\text { dysfunction }}$ \\
\hline Er et al $2012^{29}$ & $\begin{array}{l}\text { Adult patients with moderately } \\
\text { impaired renal function undergoing } \\
\text { elective } \mathrm{PCl}\end{array}$ & 100 & $\begin{array}{l}\text { Four-5 min upper arm cuff } \\
\text { inflations/deflations }\end{array}$ & $\begin{array}{l}\text { Reduction from } 40 \% \text { to } 16 \% \text { in the } \\
\text { incidence of contrast-AKI (defined as an } \\
\text { increase in serum } \mathrm{Cr} \geq 25 \% \text { or } \geq 0.5 \mathrm{mg} / \mathrm{dL} \\
\text { above baseline at } 48 \mathrm{hr}\end{array}$ \\
\hline
\end{tabular}

AAA- abdominal aortic aneurysm, EVAR- endovascular aortic aneurysm repair, CABG- coronary artery bypass graft, PCl- percutaneous coronary intervention, OPCABG- off-pump coronary artery bypass graft, RIC-remote ischemic conditioning, Cr- creatinine, $\mu$ mol- micromoles, Llitre, dL- decilitre, mg- milligram, AKI- acute kidney injury, AKIN- acute kidney injury network, NGAL- neutrophil gelatinase-associated lipocalin, eGFR- estimated glomerular filtration rate 
Table 2a: Major experimental studies investigating the effect of RIC on preventing acute

\section{lung IRI}

\begin{tabular}{|c|c|c|c|}
\hline $\begin{array}{l}\text { Experimental } \\
\text { study }\end{array}$ & Experimental setting & RIC protocol & Result of RIC \\
\hline${\underset{34}{34}}_{\text {Peralta et al } 2001}$ & $\begin{array}{l}\text { Rat model of acute liver acute } 90 \\
(90 \mathrm{~min} I / \mathrm{R})\end{array}$ & $\begin{array}{l}\text { One-10 min cycle of hepatic } \\
\text { IR }\end{array}$ & Attenuated neutrophil accumulation in lungs. \\
\hline$\underset{103}{\text { Harkin et al } 2002}$ & $\begin{array}{l}\text { Porcine model of acute lung IRI (2 } \\
\mathrm{hr} \mathrm{I/2.5} \mathrm{hr} \mathrm{R)}\end{array}$ & $\begin{array}{l}\text { Three- } 5 \text { min cycles of bilateral } \\
\text { hindlimb IR }\end{array}$ & $\begin{array}{l}\text { Reduced markers of systemic inflammation (TNF } \\
\text { and interleukin- } 6 \text {, and attenuated phagocytic cell } \\
\text { priming and pulmonary oedema/respiratory } \\
\text { failure. }\end{array}$ \\
\hline Xia et al $2003^{104}$ & $\begin{array}{l}\text { Sheep model of repeated } \\
\text { myocardial ischemia induced by } 10 \\
\text { min clamping of LAD, LCx then } \\
\text { RCA. }\end{array}$ & $\begin{array}{l}\text { Three- } 5 \text { min cycles of iliac } \\
\text { artery IR }\end{array}$ & $\begin{array}{l}\text { Attenuated increase in pulmonary vascular } \\
\text { resistance and pulmonary artery pressure and a } \\
\text { smaller reduction in } \mathrm{PaO}_{2}\end{array}$ \\
\hline $\mathrm{W}_{105}$ aldow et al 2005 & $\begin{array}{l}\text { Porcine model of acute lung IRI } \\
(1.5 \mathrm{hr} \mathrm{I} \mathrm{/5} \mathrm{hr} \mathrm{R)}\end{array}$ & $\begin{array}{l}\text { Three-5 min cycles of left } \\
\text { common femoral artery IR }\end{array}$ & $\begin{array}{l}\text { Prevention of acute lung } I R I \text { and pulmonary } \\
\text { hypertension. }\end{array}$ \\
\hline$\underset{106}{\text { Olguner et al } 2006}$ & $\begin{array}{l}\text { Rat model of acute hindlimb IRI (4 } \\
\mathrm{hr} \mathrm{I/2} \mathrm{hr} \mathrm{R)}\end{array}$ & $\begin{array}{l}\text { Three-10 min cycles of } \\
\text { hindlimb IR }\end{array}$ & $\begin{array}{l}\text { Attenuated neutrophil accumulation in lungs. } \\
\text { Reduced histological changes in lung. }\end{array}$ \\
\hline $\begin{array}{l}\text { Kharbanda et al } \\
2006^{107}\end{array}$ & $\begin{array}{l}\text { Porcine model of cardiopulmonary } \\
\text { bypass }\end{array}$ & $\begin{array}{l}\text { Four-5 min cycles of hindlimb } \\
\text { IR }\end{array}$ & $\begin{array}{l}\text { Improved lung compliance, attenuated increase } \\
\text { in pulmonary resistance and a lower peak } \\
\text { inspiratory pressure. }\end{array}$ \\
\hline
\end{tabular}

I-ischemia, R-reperfusion, IR-ischemia and reperfusion, IRI-ischemia-reperfusion injury, LAD- left anterior descending, LCx- left circumflex, RCAright coronary artery, RIC-remote ischemic conditioning ,TNF- tissue necrosis factor, PaO2- partial pressure of oxygen 
Table 2b: Major clinical studies investigating the effect of RIC the effect of RIC on preventing

\section{acute lung $\mid \mathrm{RI}$}

\begin{tabular}{|c|c|c|c|c|}
\hline Clinical study & Clinical setting & $\mathbf{N}$ & RIC protocol & Result of RIC \\
\hline Li et al $2001^{35}$ & Adult CABG surgery & 40 & $\begin{array}{l}\text { Two cycles of } 3 \text { min aortic } \\
\text { cross clamping and } 2 \text { min } \\
\text { declamping }\end{array}$ & $\begin{array}{l}\text { Reduced ventilation requirements, } \\
\text { pulmonary oedema and haemorrhage, } \\
\text { and decreased leukocyte count found on } \\
\text { lung biopsies taken after } 1 \text { hour of } \\
\text { reperfusion. }\end{array}$ \\
\hline $\begin{array}{l}\text { Cheung et al } 2006 \\
\text { Co8 }\end{array}$ & $\begin{array}{l}\text { Pediatric cardiac surgery for } \\
\text { congenital heart disease }\end{array}$ & 37 & $\begin{array}{l}\text { Four- } 5 \text { min cycles of thigh } \\
\text { cuff ischemia and } \\
\text { reperfusion }\end{array}$ & $\begin{array}{l}\text { Lower airway resistance at } 6 \mathrm{hr} \\
\text { postoperatively. }\end{array}$ \\
\hline $\begin{array}{l}\text { Rahman et al } \\
2010^{97}\end{array}$ & Adult CABG surgery & 162 & $\begin{array}{l}\text { Three- } 5 \text { min cycles of arm } \\
\text { cuff ischemia and } \\
\text { reperfusion }\end{array}$ & $\begin{array}{l}\text { No effect on ventilation time and } \\
\text { preoperative and postoperative } \mathrm{PaO}_{2} / \mathrm{FiO}_{2} \\
\text { ratios. }\end{array}$ \\
\hline Zhou et al $2010^{109}$ & $\begin{array}{l}\text { Pediatric cardiac surgery for } \\
\text { congenital heart disease }\end{array}$ & 60 & $\begin{array}{l}\text { Three-5 min cycles of arm } \\
\text { cuff ischemia and } \\
\text { reperfusion } 24 \mathrm{hrs} \text { and } 1 \mathrm{hr} \\
\text { pre-operatively }\end{array}$ & $\begin{array}{l}\text { Better lung compliance (Cs) and dynamic } \\
\text { lung compliance. }\end{array}$ \\
\hline Li et al $2010^{110}$ & Adult valvular heart surgery & 81 & $\begin{array}{l}\text { Three- } 4 \text { min cycles of thigh } \\
\text { cuff ischemia and } \\
\text { reperfusion }\end{array}$ & No effect on ventilation time. \\
\hline $\begin{array}{l}\text { Thielmann et al } \\
2010^{96}\end{array}$ & Adult CABG surgery & 53 & $\begin{array}{l}\text { Three- } 5 \text { min cycles of arm } \\
\text { cuff ischemia and } \\
\text { reperfusion }\end{array}$ & No effect on ventilation time. \\
\hline Lin et al $2010^{111}$ & $\begin{array}{l}\text { Lower limb orthopaedic surgery } \\
\text { with } 75 \text { min lower leg ischemia. }\end{array}$ & 30 & $\begin{array}{l}\text { Three- } 5 \text { min cycles of leg } \\
\text { cuff ischemia and } \\
\text { reperfusion }\end{array}$ & Reduced pulmonary injury. \\
\hline $\begin{array}{l}\text { Young et al } 2012 \\
112\end{array}$ & Adult high-risk CABG surgery & 96 & $\begin{array}{l}\text { Three- } 5 \text { min cycles of arm } \\
\text { cuff ischemia and } \\
\text { reperfusion }\end{array}$ & Increased ventilation time \\
\hline$\underset{102}{\text { Hong et al } 2012}$ & Adult OPCAB surgery & 70 & $\begin{array}{l}\text { Four- } 5 \text { min cycles of thigh } \\
\text { cuff ischemia and } \\
\text { reperfusion prior to after } \\
\text { anastomoses. }\end{array}$ & No effect on $\mathrm{PaO}_{2} / \mathrm{FiO}_{2}$ ratio \\
\hline Kim et al $20122^{113}$ & $\begin{array}{l}\text { Adults complex valvular heart } \\
\text { surgery }\end{array}$ & 54 & $\begin{array}{l}\text { Three-10 min cycles of } \\
\text { thigh cuff ischemia and } \\
\text { reperfusion prior to after } \\
\text { bypass. }\end{array}$ & $\begin{array}{l}\text { No effect on } \mathrm{PaO}_{2} / \mathrm{FiO}_{2} \text { or incidence of } \\
\text { acute lung injury (was defined as } \\
\mathrm{PaO}_{2} / \mathrm{FiO} 2<300 \mathrm{~mm} \mathrm{Hg} \text {, the detection of } \\
\text { bilateral pulmonary infiltrates on frontal } \\
\text { chest radiography and no clinical evidence } \\
\text { of further elevation in the left atrial } \\
\text { pressure. }\end{array}$ \\
\hline $\begin{array}{l}\text { Lomivorotov et al } \\
2012^{114}\end{array}$ & Adult CABG surgery & 80 & $\begin{array}{l}\text { Three- } 5 \text { min cycles of arm } \\
\text { cuff ischemia and } \\
\text { reperfusion }\end{array}$ & No effect on ventilation time \\
\hline
\end{tabular}

tension/Fraction of inspired oxygen ratio, Cs- static compliance, $\mathrm{mmHg}$ - millimetres of mercury 
Table 3: Major experimental studies investigating the effect of RIC on preventing acute liver

$\mid \mathrm{RI}$

\begin{tabular}{|c|c|c|c|}
\hline $\begin{array}{l}\text { Experimental } \\
\text { study }\end{array}$ & Experimental setting & RIC protocol & Effect of RIC \\
\hline Lai et al $2006^{40}$ & $\begin{array}{l}\text { Rat model of partial liver (left lobe } \\
\text { only) IRI } 45 \mathrm{~min} \mathrm{I/240} \mathrm{min} \mathrm{R}\end{array}$ & $\begin{array}{l}\text { Four- } 10 \text { min cycles of IR to } \\
\text { hindlimb }\end{array}$ & $\begin{array}{l}\text { Attenuated increase in serum ALT. } \\
\text { Increased hepatocyte expression of HO-1 }\end{array}$ \\
\hline$\underset{115}{\text { Kanoria et al } 2006}$ & $\begin{array}{l}\text { Rabbit model of liver acute IRI } 25 \\
\text { min I/ } 120 \text { min R }\end{array}$ & $\begin{array}{l}\text { Three- } 10 \text { min cycles of IR to } \\
\text { hindlimb }\end{array}$ & $\begin{array}{l}\text { Attenuated rise in ALT/AST levels } \\
\text { Preserved PLBF } \\
\text { Increased hepatic nitrite/nitrate levels. }\end{array}$ \\
\hline $\begin{array}{l}\text { Gustaffson et al } \\
2006^{116}\end{array}$ & $\begin{array}{l}\text { Rat model of } \\
\text { mild liver IRI } 60 \text { min I/60 min R } \\
\text { (occlusion of hepatic artery only) } \\
\text { severe liver IRI } 60 \text { min I/60 min R } \\
\text { (occlusion of hepatic vascular } \\
\text { supply). }\end{array}$ & $\begin{array}{l}\text { One } 10 \text { min episode of } \\
\text { hindlimb ischemia }\end{array}$ & $\begin{array}{l}\text { Attenuated increase in serum ALT levels but no } \\
\text { difference in PLBF following mild ischemia. No } \\
\text { difference in ALT or PLBF in severe hepatic } \\
\text { ischemia. }\end{array}$ \\
\hline$\underset{117}{T}$ Tapuria et al 2009 & $\begin{array}{l}\text { Rat model of partial liver IRI } \\
45 \text { min } 1 / 180 \text { min } R\end{array}$ & $\begin{array}{l}\text { Four- } 4 \text { min cycles of IR to } \\
\text { hindlimb }\end{array}$ & $\begin{array}{l}\text { Increased red blood cell velocity, sinusoidal flow } \\
\text { and sinusoidal perfusion along with decreased } \\
\text { neutrophil adhesion and cell death. }\end{array}$ \\
\hline Wang et al $2010^{41}$ & $\begin{array}{l}\text { Murine model of partial liver } \\
\text { ischemia } 60 \mathrm{~min} \mathrm{l/R}\end{array}$ & $\begin{array}{l}\text { One } 10 \text { min episode of } \\
\text { hindlimb ischemia. }\end{array}$ & $\begin{array}{l}\text { Attenuated increase in serum ALT. } \\
\text { Reduced serum and hepatocyte expression of } \\
\text { TNF-a, and less apoptotic cell death. } \\
\text { Increased expression of serum HMG-B1, which } \\
\text { acts on TLR4. } \\
\text { No RIC in TLR4 deficient mice. }\end{array}$ \\
\hline $\begin{array}{l}\text { Abu-Amara et al } \\
2011\end{array}$ & $\begin{array}{l}\text { Murine model of partial liver acute } \\
\text { IRI } 40 \text { min l/ } 120 \text { min R }\end{array}$ & $\begin{array}{l}\text { Six-4 min cycles of IR to } \\
\text { hindlimb }\end{array}$ & $\begin{array}{l}\text { Attenuated rise in ALT/AST levels. } \\
\text { Preserved electron microscopic/histological } \\
\text { appearances } \\
\text { RIC blocked by NO inhibitor }\end{array}$ \\
\hline $\begin{array}{l}\text { Abu-Amara et al } \\
2011\end{array}$ & $\begin{array}{l}\text { Murine model of partial liver acute } \\
\text { IRI } 40 \text { min l/ } 120 \text { min R }\end{array}$ & $\begin{array}{l}\text { Six- } 4 \text { min cycles of IR to } \\
\text { hindlimb }\end{array}$ & $\begin{array}{l}\text { Attenuated rise in ALT/AST levels. } \\
\text { Preserved electron microscopic/histological } \\
\text { appearances } \\
\text { No RIC in eNOS deficient mice. }\end{array}$ \\
\hline 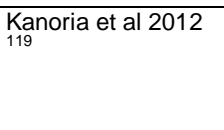 & $\begin{array}{l}\text { Rabbit model of liver acute IRI } 25 \\
\min \text { l/ } 120 \text { min R }\end{array}$ & $\begin{array}{l}\text { Three- } 10 \text { min cycles of IR to } \\
\text { hindlimb }\end{array}$ & $\begin{array}{l}\text { Attenuated rise in ALT/AST levels } \\
\text { Increased mitochondrial oxygenation, and } \\
\text { elevated serum bicarbonate and hepatic } \\
\text { nitrite/nitrate levels. }\end{array}$ \\
\hline $\begin{array}{l}\text { Abu-Amara et al } \\
2012^{43}\end{array}$ & $\begin{array}{l}\text { Murine model of partial liver acute } \\
\text { IRI } 40 \text { min l/ } 120 \text { min R }\end{array}$ & $\begin{array}{l}\text { Six-4 min cycles of IR to } \\
\text { hindlimb }\end{array}$ & $\begin{array}{l}\text { Attenuated rise in ALT/AST levels } \\
\text { Preserved electron microscopic/histological } \\
\text { appearances } \\
\text { RIC dependant on SGC-cGMP }\end{array}$ \\
\hline Wang et al $2012^{44}$ & $\begin{array}{l}\text { Rat model of liver graft } \\
\text { transplantation }\end{array}$ & $\begin{array}{l}\text { Four- } 4 \text { min cycles of IR to } \\
\text { hindlimb }\end{array}$ & $\begin{array}{l}\text { Attenuated rise in ALT/AST levels. } \\
\text { Preserved electron microscopic/histological } \\
\text { appearances. } \\
\text { Increased graft proliferation and enhanced } \\
\text { expression of interleukin- } 6 \text { mRNA and } \\
\text { suppressed expression of TNF- } \alpha \text {. }\end{array}$ \\
\hline
\end{tabular}

I-ischemia, R-reperfusion, IR-ischemia and reperfusion, IRI-ischemia-reperfusion injury, RIC-remote ischemic conditioning, ALT- alanine aminotransferase, AST- aspartate aminotransferase, HO-1- hemoxygenase-1, PLBF- peripheral liver blood flow, TNF- $\alpha$ - tissue necrosis factor alpha, HMG-B1- High Mobility Group-Box 1, TLR4- toll-like receptor-4, NO- nitric oxide, eNOS- endothelial nitric oxide synthase, sGC- soluble guanylate cyclase, cGMP- cyclic guanosine monophosphate, mRNA- messenger ribonucleic acid 
Table 4: Major experimental studies investigating the effect of RIC on preventing acute brain

$|\mathrm{R}|$

\begin{tabular}{|c|c|c|c|}
\hline $\begin{array}{l}\text { Experimental } \\
\text { study }\end{array}$ & Experimental setting & RIC protocol & Effect of RIC \\
\hline Dave et al $2006^{53}$ & $\begin{array}{l}\text { Rat model of ASA for } 8 \mathrm{~min} \text { and } \\
\text { assessment at } 7 \text { days. }\end{array}$ & $\begin{array}{l}\text { One } 15 \text { or } 30 \text { min episode of } \\
\text { ischemia applied to both } \\
\text { hindlimbs } 48 \text { hrs prior to ASA. }\end{array}$ & Preservation of CA1 hippocampal neurones \\
\hline$\underset{120}{\text { Gurcun et al } 2006}$ & $\begin{array}{l}\text { Rabbit model of abdominal aortic } \\
\text { occlusion ( } 40 \mathrm{~min} \text { ) and reflow ( } 24 \\
\text { hrs) to induce acute spinal cord IRI }\end{array}$ & $\begin{array}{l}\text { Two cycles of } 5 \text { min renal I } \\
\text { and } 15 \text { min renal } R .\end{array}$ & Improved neurological recovery. \\
\hline Zhao et al $2007_{121}$ & $\begin{array}{l}\text { Rat model of middle cerebral artery } \\
\text { occlusion/reflow ( } 2 \mathrm{hr} \mathrm{I,} 24 \mathrm{hr} \text { R). }\end{array}$ & $\begin{array}{l}\text { Three-10 min cycles of } \\
\text { hindlimb IR }\end{array}$ & $\begin{array}{l}\text { Reduced neurological dysfunction score. } \\
\text { Reduced cerebral infarct size when RIC given } \\
1,2 \text { or } 24 \text { hrs prior to middle cerebral artery } \\
\text { occlusion but not } 12 \text { or } 48 \text { hrs prior, confirming } \\
\text { the two windows of neuroprotection with RIC. }\end{array}$ \\
\hline$\underset{122}{\text { Rehni et al } 2007}$ & $\begin{array}{l}\text { Murine model of bilateral carotid } \\
\text { artery occlusion ( } 10 \mathrm{~min} \mathrm{l} / 24 \mathrm{hr} \mathrm{R})\end{array}$ & $\begin{array}{l}\text { One } 15 \text { min episode of } \\
\text { intestinal IR }\end{array}$ & $\begin{array}{l}\text { Reduced cerebral infarct size } \\
\text { Less deterioration in motor function and short- } \\
\text { term memory. } \\
\text { RIC protection abrogated by antagonists of } \mathrm{K}_{\text {ATP }} \\
\text { channel and adenosine. }\end{array}$ \\
\hline Ren et al $2008^{123}$ & $\begin{array}{l}\text { Rat model of cerebral IRI } \\
\text { (permanent left distal middle } \\
\text { cerebral artery occlusion }+ \text { bilateral } \\
\text { common carotid artery occlusion } \\
\text { for } 30 \text { minutes). }\end{array}$ & $\begin{array}{l}\text { Three-15 min cycles of } \\
\text { hindlimb IR }\end{array}$ & $\begin{array}{l}\text { Reduced cerebral infarct size when RIC } \\
\text { administered } 24 \mathrm{hr}, 12 \mathrm{hr} \text { and immediately prior } \\
\text { to acute cerebral IRI. }\end{array}$ \\
\hline Ren et al $2009^{123}$ & $\begin{array}{l}\text { Rat model of permanent cerebral } \\
\text { IRI (permanent left distal middle } \\
\text { cerebral artery occlusion + bilateral } \\
\text { common carotid artery occlusion } \\
\text { for } 30 \text { minutes). }\end{array}$ & $\begin{array}{l}\text { Three-15 min cycles of } \\
\text { hindlimb IR applied at the } \\
\text { onset of cerebral reperfusion } \\
\text { (RIPost). }\end{array}$ & $\begin{array}{l}\text { Reduced cerebral infarct size when RIC } \\
\text { immediately and } 3 \text { hours after cerebral } \\
\text { reperfusion but not at } 6 \text { hours after reperfusion. } \\
\text { First demonstration that RIPost and delayed } \\
\text { RIPost effect. } \\
\text { RIC blocked by capsaicin and cycloheximide } \\
\text { implicating afferent nerve stimulation and protein } \\
\text { synthesis in the mechanism. }\end{array}$ \\
\hline 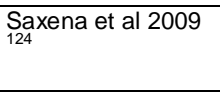 & $\begin{array}{l}\text { Rat model of transient } \mathrm{GCl}, 8 \mathrm{~min} \\
\text { bilateral common carotid artery } \\
\text { occlusion and hypotension. }\end{array}$ & $\begin{array}{l}\text { Five- } 5 \text { min cycles of hindlimb } \\
\text { IR }\end{array}$ & $\begin{array}{l}\text { No effect on CA1 hippocampal neurones. } \\
\text { This is probably because of the index ischemic } \\
\text { event not being insufficient. }\end{array}$ \\
\hline $\begin{array}{l}\text { Yannopoulos et al } \\
2010^{125}\end{array}$ & $\begin{array}{l}\text { Piglet model of cardiopulmonary } \\
\text { bypass and hypothermic } \\
\text { circulatory arrest }\end{array}$ & $\begin{array}{l}\text { Four-5 min cycles of hindlimb } \\
\text { IR }\end{array}$ & $\begin{array}{l}\text { Reduced cerebral lactate, glucose and glycerol } \\
\text { levels. } \\
\text { More rapid recovery of EEG activity. }\end{array}$ \\
\hline Xu et al $2011^{126}$ & $\begin{array}{l}\text { Rat model bilateral carotid artery } \\
\text { occlusion ( } 60 \text { min } 1 / 5-8 \text { days } R \text { ) }\end{array}$ & $\begin{array}{l}\text { Three-10 min cycles of } \\
\text { hindlimb IR }\end{array}$ & $\begin{array}{l}\text { Improved neurocognitive function. } \\
\text { Increased expression for anti-apoptotic protein } \\
\text { Bcl2. }\end{array}$ \\
\hline $\begin{array}{l}\text { Malhotra et al } \\
2011^{127}\end{array}$ & $\begin{array}{l}\text { Rat model of middle cerebral artery } \\
\text { occlusion ( } 2 \mathrm{hrs} \text { ) and reflow ( } 24 \\
\text { hrs) }\end{array}$ & $\begin{array}{l}\text { Three- } 10 \text { min cycles of } \\
\text { infrarenal aortic occlusion and } \\
\text { reflow. }\end{array}$ & $\begin{array}{l}\text { Reduced cerebral infarct size when RIC stimulus } \\
\text { applied } 24 \text { hrs but not } 48 \text { or } 72 \text { hrs prior to acute } \\
\text { cerebral IRI. } \\
\text { Improved neurological outcomes } \\
\text { RIC protection abrogated by hexamethonium } \\
\text { implicating a neural pathway in protection. }\end{array}$ \\
\hline$J_{128}$ ensen et al 2011 & $\begin{array}{l}\text { Piglet model of cardiopulmonary } \\
\text { bypass and hypothermic } \\
\text { circulatory arrest }\end{array}$ & $\begin{array}{l}\text { Four-5 min cycles to hindlimb } \\
\text { IR }\end{array}$ & $\begin{array}{l}\text { Reduced cerebral lactate levels. } \\
\text { Less cerebral injury on histological analysis. } \\
\text { More rapid recovery of EEG activity. } \\
\text { Improved neurological recovery. }\end{array}$ \\
\hline Zhou et al $2011^{129}$ & $\begin{array}{l}\text { Neonatal rat model cerebral } \\
\text { hypoxia (unilateral carotid ligation } \\
\text { and } 2 \text { hrs of hypoxia) }\end{array}$ & $\begin{array}{l}\text { Four-10 min cycles of IR to } \\
\text { both hindlimbs at the onset of } \\
\text { cerebral reoxygenation/ } \\
\text { reperfusion (RIPost). }\end{array}$ & $\begin{array}{l}\text { Reduced cerebral infarct size } \\
\text { Improved neurological recovery. } \\
\text { RIC blocked by naloxone and wortmannin } \\
\text { implicating opioid receptor and PI3K signalling in } \\
\text { protective response. } \\
\text { RIC associated with PKB activation and less } \\
\text { BAX. }\end{array}$ \\
\hline$\underset{130}{\mathrm{Hahn}}$ et al 2011 & $\begin{array}{l}\text { Rat model of middle cerebral artery } \\
\text { occlusion ( } 2 \mathrm{hrs} \text { ) and reflow ( } 24 \\
\text { hrs) }\end{array}$ & $\begin{array}{l}\text { Four-5 min cycles to hindlimb } \\
\text { IR }\end{array}$ & $\begin{array}{l}\text { Reduced cerebral infarct size when RIC stimulus } \\
\text { applied prior to and after the onset of cerebral } \\
\text { ischemia. } \\
\text { First demonstration that RIPerC in brain. }\end{array}$ \\
\hline Sun et al $2012^{131}$ & $\begin{array}{l}\text { Rat model of middle cerebral artery } \\
\text { occlusion ( } 90 \mathrm{~min}) \text { and reflow ( } 72 \\
\text { hrs) }\end{array}$ & $\begin{array}{l}\text { Three- } 5 \text { min cycles of IR to } \\
\text { both hindlimbs (RIPost). }\end{array}$ & $\begin{array}{l}\text { Reduced cerebral infarct size when RIC stimulus } \\
\text { applied at } 3 \text { or } 6 \text { hours into reperfusion. } \\
\text { RIC protection via mitochondrial } \mathrm{K}_{\text {ATP }} \text { channel. }\end{array}$ \\
\hline$\underset{132}{\text { Geng et al } 2012}$ & $\begin{array}{l}\text { Rat model of intracerebral } \\
\text { haemorrhage using collagenase. }\end{array}$ & $\begin{array}{l}\text { Repeated episodes of IR to } \\
\text { both hindlimbs. }\end{array}$ & $\begin{array}{l}\text { No beneficial effects on cerebral blood volumes, } \\
\text { brain water content, Evans blue extravasations, } \\
\text { and expressions of AQP-4 and MMP-9 or }\end{array}$ \\
\hline
\end{tabular}




\begin{tabular}{|l|l|l|l|}
\hline Wei et al $2012^{133}$ & $\begin{array}{l}\text { Rat model of permanent cerebral } \\
\text { IRI (permanent left distal middle } \\
\text { cerebral artery occlusion + bilateral } \\
\text { common carotid artery occlusion } \\
\text { for } 30 \text { minutes). }\end{array}$ & $\begin{array}{l}\text { Three-15 min cycles of } \\
\text { hindlimb IR. }\end{array}$ & $\begin{array}{l}\text { Reduced cerebral infarct size at } 2 \text { and } 60 \text { days } \\
\text { with improved neurological recovery at } 2 \text { months. } \\
\text { Less cerebral edema and reduced blood brain- } \\
\text { barrier permeability. } \\
\text { RIC protection via afferent neural pathway. } \\
\text { Attenuated increase in inflammatory protein } \\
\text { galectin-9 and T-cell immunoglobulin domain } \\
\text { and Tim-3 and less iNOS and nitrosylation. }\end{array}$ \\
\hline Hu et al $2012^{134}$ & $\begin{array}{l}\text { Rat model of middle cerebral artery } \\
\text { occlusion (90 min) and reflow (72 } \\
\text { hrs) }\end{array}$ & $\begin{array}{l}\text { Three-5 min cycles of hindlimb } \\
\text { IR }\end{array}$ & $\begin{array}{l}\text { Reduced cerebral infarct size when RIC stimulus } \\
\text { applied at } 3 \text { or } 6 \text { hours into reperfusion. } \\
\text { RIC protection via mitochondrial K }\end{array}$ \\
\hline ATP channel.
\end{tabular}

I-ischemia, R-reperfusion, IR-ischemia and reperfusion, IRI-ischemia-reperfusion injury, RIC-remote ischemic conditioning, RIPost- remote ischemic postconditioning, RIPerC- remote ischemic perconditioning, ASA- asphyxial cardiac arrest, GCl- global cerebral ischemia, CA1- cornu ammonis-1, KATP- adenosine triphosphate-sensitive potassium, EEG- electroencephalography, bcl-2- B-cell lymphoma-2, PI3Kphosphatidylinositol 3-kinase, PKB- protein kinase B, BAX- b-cell lymphoma-2-associated X protein, AQP4- aquaporin-4, MMP-9- matrix metallopeptidase-9, Tim-3- mucin-domain-containing molecule-3, iNOS- inducible nitric oxide synthase, 


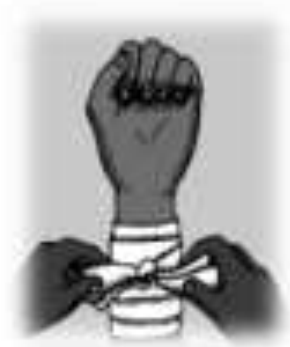

SKIN FLAP

Trauma surgery

Plastic surgery

Reconstructive surgery
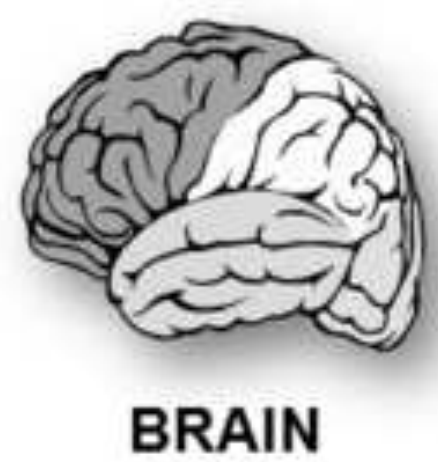

Stroke

Subarachnoid hemorrhage

Carotid endarterectomy

Cervical decompression surgery

Cerebral asphyxia
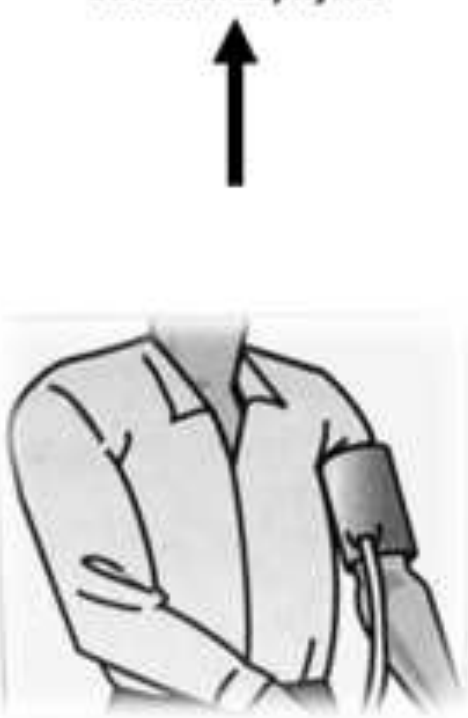

1

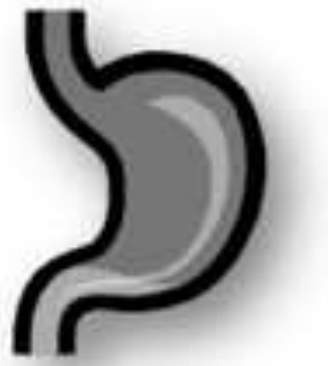

STOMACH

Gastric ischemia

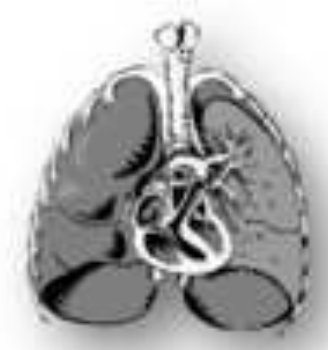

LUNGS

Resection surgery

Transplantation

Cardiac surgery

Vascular surgery

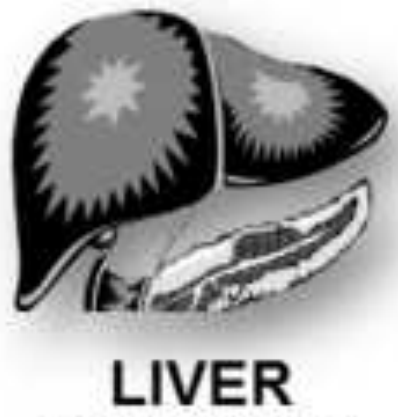

Resection surgery

Transplantation

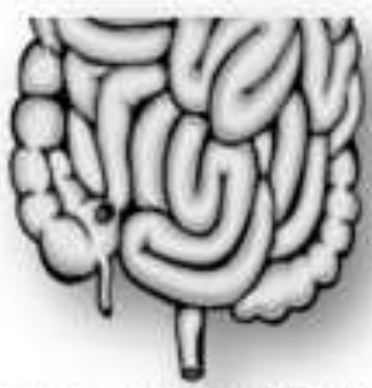

SMALL INTESTINE

Ischemic bowel
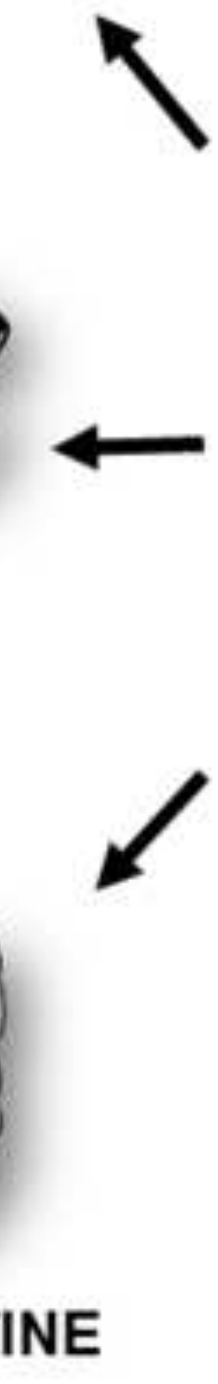